\title{
Socio-Ecological Systems (SESs)-Identification and Spatial Mapping in the Central Himalaya
}

\author{
Praveen Kumar ${ }^{1,2, *} \mathbb{C}$, Christine Fürst ${ }^{2}$ and P. K. Joshi ${ }^{1,3}$ \\ 1 School of Environmental Sciences (SES), Jawaharlal Nehru University (JNU), New Delhi 110067, India; \\ pkjoshi@mail.jnu.ac.in \\ 2 Department of Sustainable Landscape Development, Martin-Luther University Halle-Wittenberg, \\ 06120 Halle (Saale), Germany; christine.fuerst@geo.uni-halle.de \\ 3 Special Center for Disaster Research (SCDR), Jawaharlal Nehru University (JNU), New Delhi 110067, India \\ * Correspondence: pravee93_ses@jnu.ac.in
}

Citation: Kumar, P.; Fürst, C.; Joshi, P.K. Socio-Ecological Systems (SESs) - Identification and Spatial Mapping in the Central Himalaya. Sustainability 2021, 13, 7525. https:// doi.org/10.3390/su13147525

Academic Editors:

Isabel Banos-González and Julia Martínez-Fernández

Received: 5 April 2021

Accepted: 28 June 2021

Published: 6 July 2021

Publisher's Note: MDPI stays neutral with regard to jurisdictional claims in published maps and institutional affiliations.

Copyright: (c) 2021 by the authors. Licensee MDPI, Basel, Switzerland. This article is an open access article distributed under the terms and conditions of the Creative Commons Attribution (CC BY) license (https:// creativecommons.org/licenses/by/ $4.0 /)$.

\begin{abstract}
The Himalaya is a mosaic of complex socio-ecological systems (SESs) characterized by a wide diversity of altitude, climate, landform, biodiversity, ethnicity, culture, and agriculture systems, among other things. Identifying the distribution of SESs is crucial for integrating and formulating effective programs and policies to ensure human well-being while protecting and conserving natural systems. This work aims to identify and spatially map the boundaries of SESs to address the questions of how SESs can be delineated and what the characteristics of these systems are. The study was carried out for the state of Uttarakhand, India, a part of the Central Himalaya. The presented approach for mapping and delineation of SESs merges socio-economic and ecological data. It also includes validation of delineated system boundaries. We used 32 variables to form socio-economic units and 14 biophysical variables for ecological units. Principal component analysis followed by sequential agglomerative hierarchical cluster analysis was used to delineate the units. The geospatial statistical analysis identified 6 socio-economic and 3 ecological units, together resulting in 18 SESs for the entire state. The major characteristics for SESs were identified as forest types and agricultural practices, indicating the influence and dependency of SESs on these two features. The database would facilitate diverse application studies in vulnerability assessment, climate change adaptation and mitigation, and other socio-ecological studies. Such a detailed database addresses particularly site-specific characteristics to reduce risks and impacts. Overall, the identified SESs will help in recognizing local needs and gaps in existing policies and institutional arrangements, and the given methodological framework can be applied for the entire Himalayan region and for other mountain systems across the world.
\end{abstract}

Keywords: clustering; ecological units; mapping; PCA; socio-ecological systems; socio-economic units

\section{Introduction}

Understanding complex interactions and interrelations between humans and their environment is necessary for planning and policy formulation for attaining sustainable development goals. Human systems and natural ecosystems are closely linked in a given space and time [1], forming a socio-ecological system (SES) [2,3], which is referred to in earlier studies as coupled human-environment systems [4] or coupled natural and human systems $[3,5,6]$. Nowadays, the terms "socio-ecological system" and "social-ecological system" are used synonymously in environmental sciences to represent the interrelationship and dynamics between ecological and social systems. In an SES, social entities interact and alter natural resources of the ecological systems in multiple ways and at different levels $[5,6]$. In previous empirical studies, these interactions have been examined without accounting for the dynamics and the complexity of the coupled systems [7-12], which is rarely understood and documented $[13,14]$. Such a lack of understanding is due to 
incoherent separation between social and ecological sciences, leading to insufficient comprehensive analyses for sustainability $[15,16]$. The differences in associations between social and ecological systems can cause unsustainable use of resources [6,17]. Thus, the understanding of these associations in an SES is pertinent in achieving sustainability [18]. Although some researchers have studied coupled systems shaped by insights from complex adaptive systems [19-21], most of the previous works have been theoretical rather than empirical. Thus, SES research needs innovative transdisciplinary methodologies to understand the characteristics and associations of its two domains [6].

The spatial mapping of coupled SESs was a subject of interest in earlier studies $[1,10,11$, 22]. These were either to a limited geographical extent or focused on a particular characteristic of a system. However, many studies have a limited focus on the socio-economic aspects and their implications on ecosystem states in the mapping. In cross-disciplinary studies, interactions between different levels of SESs and their components and decision-makers are often not addressed. The mapping of SESs has the potential to reveal the complex relationships between the social and ecological systems. Martín-López et al. [1] mapped the SESs at the local scale for understanding and assessing whole-system interactions to operationalize the concept of SESs in landscape planning. Various mapping approaches used the actors and institutions of the social system and ecosystems, creating SES models [23,24]. There are no spatial mapping studies of the SES that focus on the Himalayan region where multiple social systems are intricately linked to their respective ecological systems through complex linkages. The characterization of SESs based on socio-economic and ecological components can be identified by a specific indicator or a set of indicators to help in formulating policies and for other assessments [25], e.g., poverty in economic development [26], and conservation in the ecoregion $[27,28]$. To date, converting theoretical concepts into practical tools such as spatial mapping of SESs and ecosystem services assessment allows identifying and understanding the complex processes and dynamics, non-linear feedback processes, and interactions across scales [29]. Each SES has a distinctive feature, in which a social system has a distinct association with the surrounding ecological systems [21]. In different SESs, the usage of natural resources by the communities is different as their association and dependence vary among them [30]. Spatial mapping of SESs through maps can never characterize their dynamics and complexity [31], but it can help in identifying the spatial characteristics and features to understand the dynamics of the SESs.

Mountains are complex SESs characterized by ecological fragility, limited accessibility, geological instability, social marginality, and natural diversity [32-35]. Unprecedented changes such as climate change, soil erosion, biodiversity loss, forest fires, glacial melting, etc., occurring in different mountain ecosystems are being reported across the world [36,37]. These changes increase the stress on the systems with ample effects on the environment, biodiversity, and socio-economic conditions [38]. The number of studies has increased in the past few years to understand the social-ecological interactions [39,40], particularly in a mountainous region [12].

The Himalaya, one of the youngest and the most fragile arrays of mountains, are important for economic growth and human well-being [41]. The region has several challenges for humans such as inaccessibility, remoteness, and poor development [42] and is also prone to many catastrophic events [43]. The geography and socio-economic settings make this region highly vulnerable to climate change, risks, and hazards [35]. The Central Himalaya is a distinctive entity with undulating topography, rugged and mountainous terrain, fragile ecosystems, and high population density [44,45]. Uttarakhand, one of the hilly states of the Central Himalaya, with above-average warming of $0.46{ }^{\circ} \mathrm{C}$ during the 20th century is one of the most vulnerable regions to climate-mediated risks [35,46]. Over the last few years, the state has seen a rapid increase in the incidence and intensity of extreme weather events such as increased temperature, altered precipitation patterns, more recurrent episodes of drought and floods, and negative biotic influences such as pest outbreaks, invasive species, forest fires, forest fragmentation, etc. [46-49]. The changes in the climate have resulted in diverse impacts and disasters $[50,51]$ and, thus, have impacted 
the functioning and productivity of the SESs. The changes in productivity, especially in agriculture and forestry severely affect the prevailing livelihood options of the Himalayan community [52]. These problems are accelerated through unplanned and unsustainable development activities, such as rapid urbanization, road constructions, and hydro-power plants [53]. Additionally, the net increase in temperature in the region in the 2030s is forecast to be between 1.7 and $2.2{ }^{\circ} \mathrm{C}$ with respect to the $1970 \mathrm{~s}$, and temperatures are also forecast to rise in all seasons $[46,54]$. As a result, these changes along with already existing changes in the climate systems make the Himalayan regions more exposed to high levels of climate change and variability, threatening biodiversity, agriculture, social systems, and other natural resources [52]. Impacts of climate change are linked to the interactions within and among the social and natural systems [55]. Thus, it is essential to understand how the vulnerability of different types of SESs will respond to climate change.

The objective of the presented research is to identify and spatially map the boundaries of SESs to understand the delineation and characteristics of these systems using the methodological approach, proposed by Martín-López et al. [1], on a large and heterogeneous area such as the Himalaya region, using Uttarakhand as an example. Our suggested delineation approach is based on large numbers of variables that characterize the major SES types and their characteristic socio-economic and environmental features. The results support and provide a database for further meta-analysis and generate recommendations for decision-making and policy planning for the preparation of climate change adaptation plans by providing insights on key factors that enhance the vulnerability of the different SES types.

\section{Materials and Methods}

\subsection{Study Area}

The study area focuses on the Uttarakhand State in the Central Himalaya. Geographically, it is situated between $28^{\circ} 43^{\prime} 24^{\prime \prime}$ to $31^{\circ} 27^{\prime} 50^{\prime \prime}$ North latitude and $77^{\circ} 34^{\prime} 27^{\prime \prime}$ to $81^{\circ} 02^{\prime} 22^{\prime \prime}$ East longitude with an area of $53,485 \mathrm{~km}^{2}$, accounting for $1.62 \%$ of the total area of the country (Figure 1). The elevation of the region ranges from 210 to $7817 \mathrm{~m}$. Administratively, the state is divided into 13 districts falling into two administrative divisions, Garhwal (north-west portion) and Kumaon (south-east portion). The entire state is characterized by a wide range of intraregional variations in topography, geology, soil, and climate as well as in socio-economic structure and living standards and development. It has an immense diversity of altitude, climate, natural resources, biodiversity, ethnicity, culture, and farming systems.

The state has a diverse topography and fragile terrain. It can broadly be divided into three physiographic zones, the Greater Himalaya (Himadri), the Lesser Himalaya (Himachal), and the Outer Himalaya (Shivaliks) running parallel to each other from northwest to southeast. The forest cover is $45.44 \%$ of its geographical area, with $9.44 \%$ very dense forest, $23.94 \%$ moderately dense forest, and $12.06 \%$ open forest [56]. The major forest types present are Himalayan moist temperate forest (31.64\%), subtropical pine forest $(29.87 \%)$, and tropical moist deciduous (20.29\%) forest.

According to the Census of India (2011), the population of Uttarakhand amounts to 10.11 million inhabitants with a population density of 189 individuals per $\mathrm{km}^{2}$. Population distribution in the state is very uneven depending upon the physiography. The state has a sex ratio of 963 females for every 1000 males and a literacy rate of $79.63 \%$. Uttarakhand is predominantly a rural state (69.45\% population lives in rural areas) with 16,826 villages, of which 12,699 or $81 \%$ have a population of fewer than 500 people. The region is sparsely populated in small settlements with high dependence on rainfed agriculture and adjoining forests. Subsistence agriculture is the main source of livelihood [57,58]. People lack basic facilities such as services and institutions in the region, making them highly dependent on natural resources [59]. 


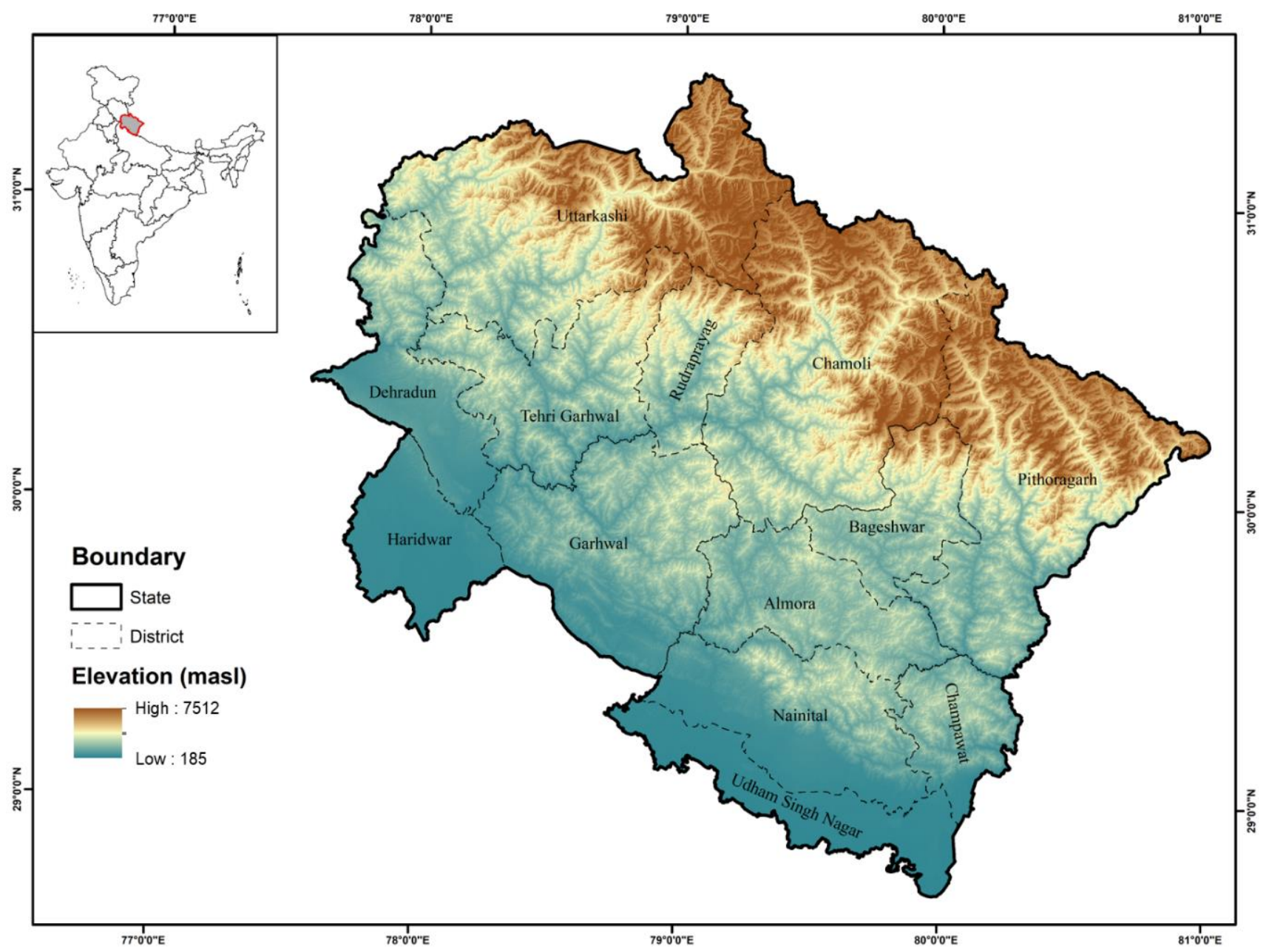

Figure 1. Map showing districts of Uttarakhand state in the Indian Himalayan region (IHR).

\subsection{Data Collection}

In all, 92 socio-economic variables, such as demography, economy, education, infrastructure, technology, health, etc., and 28 ecological variables addressing climate, geomorphology, biophysical environment, lithology, topography, and land use/cover were collected for the study area based on the earlier mountain-specific literature $[35,57,60]$, discussions with scientific community, and ground observations for a holistic understanding of the considered region (see Tables A1 and A2 in Appendix A for the complete list of all the variables used). Highly correlated variables were dropped after correlation analysis, resulting in 32 socio-economic and 14 ecological variables (Tables 1 and 2). For the socioeconomic variables, the village was taken as the data collection unit, and the entire database on ecological variables was resampled to $30 \mathrm{~m}$ cell size for consistency. Data were collected from different reliable secondary sources namely Census of India (2011), WorldClim database (1970-2000), National Bureau of Soil Survey and Land Use Planning (NBSS\&LUP), Forest Survey of India (2015), Biodiversity Characterization program (IIRS/NRSC), National Resource Repository Survey (NRSC), ASTER-GDEM (Advanced Spaceborne Thermal Emission and Reflection Radiometer-Global Digital Elevation Model), MODIS (Moderate Resolution Imaging Spectroradiometer), and a database generated in our laboratory and by others to delineate the boundaries of SESs. 
Table 1. List of variables used for socio-economic units (source: Census of India, 2011).

\begin{tabular}{|c|c|c|c|c|c|}
\hline Type & Variable Name & Code & $\begin{array}{c}\text { Numeric/ } \\
\text { Categorical (N/C) }\end{array}$ & Mean & $\begin{array}{l}\text { Standard } \\
\text { Deviation }\end{array}$ \\
\hline \multirow[t]{3}{*}{ Demographic } & Total Geographical Area (in Hectares) & G_area & $\mathrm{N}$ & 200.30 & 31.77 \\
\hline & Total Households & Hshld & $\mathrm{N}$ & 84.82 & 19.60 \\
\hline & Total Population of Village & Vil_pop & $\mathrm{N}$ & 418.82 & 10.80 \\
\hline \multirow[t]{3}{*}{ Education } & Primary Education & Prm_edu & $\mathrm{N}$ & 0.85 & 0.85 \\
\hline & Secondary Eduction & Sec_edu & $\mathrm{N}$ & 0.56 & 1.15 \\
\hline & Higher Education & Hgh_edu & $\mathrm{N}$ & 0.01 & 0.12 \\
\hline \multirow[t]{2}{*}{ Health } & HealthCare & Hlth_cr & $\mathrm{N}$ & 0.32 & 0.78 \\
\hline & Govt. Health Program & Hlth_prg & $\mathrm{C}$ & 1.40 & 0.49 \\
\hline \multirow[t]{5}{*}{ Water } & Tap Water & Tp_wtr & $\mathrm{C}$ & 1.11 & 0.31 \\
\hline & Well & Well & $\mathrm{C}$ & 1.97 & 0.18 \\
\hline & Hand Pump/Tube wells & Hnd_pmp & $\mathrm{C}$ & 1.69 & 0.46 \\
\hline & Spring & Sprng & $\mathrm{C}$ & 1.96 & 0.18 \\
\hline & River/Canal/Tank/Pond/Lake & Rvr_cnl_tk & $\mathrm{C}$ & 1.78 & 0.41 \\
\hline Post Office & Post Office & Pst_offc & $\mathrm{C}$ & 1.84 & 0.37 \\
\hline Communication & Communication & Comm & $\mathrm{C}$ & 1.11 & 0.31 \\
\hline Transportation & Transportation & Trnsprt & $\mathrm{C}$ & 1.56 & 0.50 \\
\hline Road & Road Connectivity & Road & $\mathrm{C}$ & 1.59 & 0.49 \\
\hline \multirow[t]{2}{*}{ Bank Services } & Bank Services & Bnk_srvc & $\mathrm{C}$ & 1.96 & 0.20 \\
\hline & Credit Societies & Crdt_soc & $\mathrm{C}$ & 1.71 & 0.45 \\
\hline \multirow[t]{2}{*}{ Market } & Market & Mrkt & $\mathrm{C}$ & 1.96 & 0.19 \\
\hline & $\begin{array}{c}\text { Public Distribution System (PDS) } \\
\text { Shop }\end{array}$ & Pblc_dst & C & 1.67 & 0.47 \\
\hline \multirow[t]{2}{*}{ Information } & Media & Media & $\mathrm{C}$ & 1.96 & 0.20 \\
\hline & Information & Info & $\mathrm{C}$ & 1.79 & 0.41 \\
\hline \multirow[t]{2}{*}{ Electricity } & Power Supply for Domestic Use & Pwr_dom & $\mathrm{C}$ & 1.08 & 0.27 \\
\hline & Power Supply for Agriculture Use & Pwr_agri & $\mathrm{C}$ & 1.86 & 0.34 \\
\hline \multirow[t]{7}{*}{ Agriculture } & $\begin{array}{c}\text { Total Unirrigated Land Area (in } \\
\text { Hectares) }\end{array}$ & Unirrgt & $\mathrm{N}$ & 30.06 & 2.78 \\
\hline & Area Irrigated by Source (in Hectares) & Irrigt & $\mathrm{N}$ & 18.63 & 6.00 \\
\hline & $\begin{array}{c}\text { Culturable Waste Land Area (in } \\
\text { Hectares) }\end{array}$ & Cltr_wst & $\mathrm{N}$ & 18.05 & 4.18 \\
\hline & $\begin{array}{l}\text { Fallows Land Other Than Current } \\
\text { Fallows Area (in Hectares) }\end{array}$ & Fllw_lnd & $\mathrm{N}$ & 2.92 & 0.74 \\
\hline & Current Fallows Area (in Hectares) & Fllw_crnt & $\mathrm{N}$ & 2.47 & 1.60 \\
\hline & Net Area Sown (in Hectares) & Nt_swn & $\mathrm{N}$ & 46.61 & 8.22 \\
\hline & Agriculture Equipment & Agri_eqp & $\mathrm{C}$ & 1.93 & 0.26 \\
\hline
\end{tabular}

Table 2. List of variables used to form ecological units.

\begin{tabular}{|c|c|c|c|c|}
\hline Type & Variable Name & Code & Source & Resolution \\
\hline \multirow[t]{9}{*}{ Climatic } & Climatic Annual Mean Temperature & B1 & WorldClim & $1 \mathrm{~km}$ \\
\hline & Mean Diurnal Range & B2 & WorldClim & $1 \mathrm{~km}$ \\
\hline & $\begin{array}{c}\text { Isothermality } \\
(\mathrm{BIO} 2 / \mathrm{BIO} 7)(\times 100)\end{array}$ & B3 & WorldClim & $1 \mathrm{~km}$ \\
\hline & $\begin{array}{l}\text { Temperature Seasonality } \\
(\text { Standard Deviation } \times 100)\end{array}$ & B4 & WorldClim & $1 \mathrm{~km}$ \\
\hline & $\begin{array}{l}\text { Temperature Annual Range (BIO } \\
\text { 5-BIO 6) }\end{array}$ & B7 & WorldClim & $1 \mathrm{~km}$ \\
\hline & Annual Precipitation & B12 & WorldClim & $1 \mathrm{~km}$ \\
\hline & Precipitation of Driest Month & B14 & WorldClim & $1 \mathrm{~km}$ \\
\hline & $\begin{array}{l}\text { Precipitation Seasonality } \\
\text { (Coefficient of Variation) }\end{array}$ & B15 & WorldClim & $1 \mathrm{~km}$ \\
\hline & Precipitation of Driest Quarter & B17 & WorldClim & $1 \mathrm{~km}$ \\
\hline \multirow[t]{2}{*}{ Geomorphologic } & Aspect & Asp & ASTER-GDEM & $30 \mathrm{~m}$ \\
\hline & Slope & Slp & ASTER-GDEM & $30 \mathrm{~m}$ \\
\hline Pedologic & Soil type & Soil & $\begin{array}{l}\text { National Bureau of Soil } \\
\text { Survey and Land Use } \\
\text { Planning }\end{array}$ & $1: 50,000$ \\
\hline $\begin{array}{l}\text { Land Use/ } \\
\text { Land Cover }\end{array}$ & LULC & LULC & $\begin{array}{l}\text { National Remote } \\
\text { Sensing Center }\end{array}$ & $1: 50,000$ \\
\hline Forest Cover & Forest Types & Frst & Forest Survey of India & $1: 50,000$ \\
\hline
\end{tabular}




\subsection{Data Processing and Analysis}

The SES boundary delineation and mapping were carried out with modifications in the methodological approach proposed by Martín-López et al. [1] on a large and heterogeneous area. It was performed in four steps (Figure 2) (a) socio-economic unit identification and characterization, (b) ecological unit identification and characterization, (c) delineation of SES boundaries, and (d) characterization of SES boundaries. R-studio software was used for statistical analysis of the data collected from primary and secondary sources. ArcGIS (ver. 10.1) was used for mapping and spatial analysis.

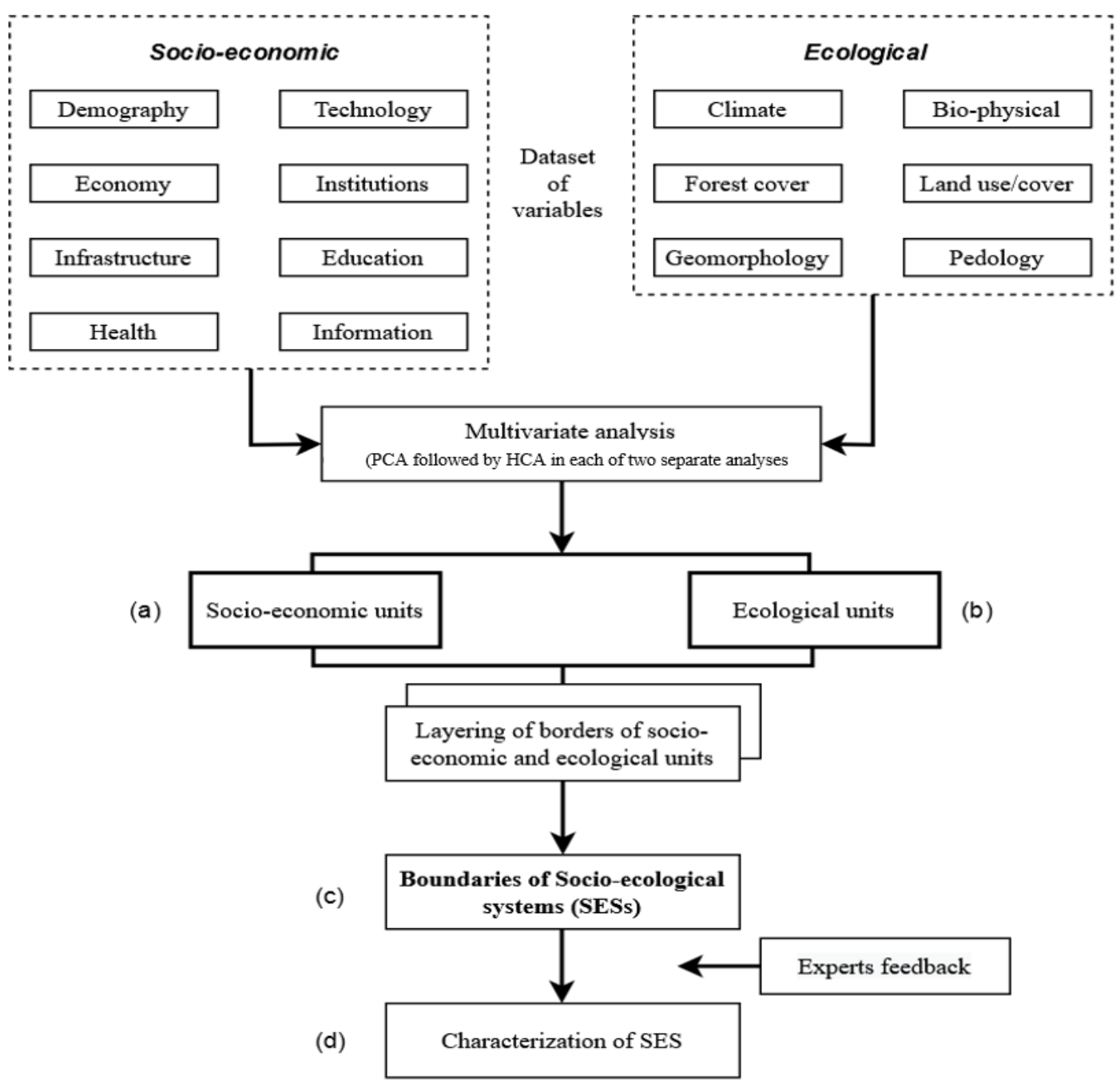

Figure 2. The methodological framework used to identify and delineate socio-ecological system boundaries. In multivariate analysis, PCA is followed by HCA for both datasets of variables in a separate analysis (adapted from Martín-López et al. [1]).

Multivariate data analysis was performed in R-studio using the "FactoMineR", "factoextra", and "ggplot2" packages. Standardization of the variables with different units was done before the analysis, as variables are measured at different scales, which do not contribute equally to the analysis and might end up creating a bias. The Kaiser-MeyerOlkin (KMO) test [61] was performed to measure sampling adequacy of both datasets of variables (Equation (1)). The KMO test indicates the proportion of variance in variables that might be caused by underlying factors. The KMO test is represented as

$$
K M O_{j}=\frac{\sum_{i \neq j} r_{i j}^{2}}{\sum_{i \neq j} r_{i j}^{2}+\sum_{i \neq j} u}
$$


where $r_{i j}$ is the correlation matrix and $u_{i j}$ is the partial covariance matrix. The KMO value range between 0 to 1 , and if the value is lower than 0.6 , then the sampling is not adequate. Bartlett's test of sphericity [62] was done to test the hypothesis that the correlation matrix is an identity matrix, which indicates that variables are unrelated and, therefore, unsuitable for structure detection. Small values $(p<0.05)$ of the significance level indicate that data are suitable for principal component analysis (PCA).

For socio-economic units, the villages were considered for clustering since they represent the lowest administrative level. For the delineation of the ecological entities, the state was divided into $250 \mathrm{~m}$ grid cells to maintain the data uniformity, and the values for each biophysical variable were calculated for each cell. Subsequently, the values of the variables for socio-economic and ecological units (Tables 1 and 2) were used in PCA to extract key components for the joint delineation of the SESs. PCA identifies linear independent dimensions by analyzing the similarities between the data points (Equation (2)). PCA is done before clustering for efficiency purposes as algorithms that perform clustering are more efficient for lower-dimensional data. The main objective of PCA is to reduce a dataset ( $X$ dataset with $m$ individuals and $n$ variables) with a smaller number of uncorrelated variables $(X<n)$ while retaining as much information as possible. Let $X=\left[x_{i}\right]$ be any $k \times 1$ random vector. We define a $k \times 1$ vector $Y=\left[y_{i}\right]$, where for each $i$ the $i$ th principal component of $X$ is

$$
y_{i}=\sum_{j=1}^{k} \beta_{i j} x_{j}
$$

For some regression coefficients $\beta_{i j}$. Since each $y_{i}$ is a linear combination of the $x_{i}, Y$ is a random vector.

Sequential agglomerative hierarchical cluster analysis (HCA) was applied to the PCs with an eigenvalue greater than 1 (Kaiser criteria), using Euclidean distance and Ward's method [63] to compute the similarity. It is a stepwise algorithm in which two objects with the least dissimilarity are merged at each step (Equation (3)). The basic concept behind the clustering is Minimize $=$ (Within cluster variance $/$ between cluster variance) .

$$
\operatorname{sim}\left(X_{1}, X_{2} \ldots n_{i}\right)=\left[\left(\frac{\left|X_{1}\right| \times\left|X_{2}\right|}{\left|X_{1}\right|+\left|X_{2}\right|}\right)\right] \times \sum\left[\operatorname{dist}\left(M_{i}, M_{j} \ldots x_{k}\right)\right]^{2}
$$

where, $X_{1}, X_{2}, \ldots n_{i}$ are clusters and $M_{i}, M_{j}, \ldots x_{k}$ are points. The similarity of clusters $X_{1}$, $X_{2}, \ldots n_{i}$ is equal to the maximum of the similarity between points $M_{i}, M_{j}, \ldots x_{k}$ such that $M_{i}$ belongs to $X_{1}$, and $M_{j}$ belongs to $X_{2}$ cluster and $n$ belongs to $x_{k}$ belongs to $n_{i}$ cluster.

The outcome of this analysis is a binary tree, also called a dendrogram, with $n-1$ nodes characterizing the homogeneous characteristics of a cluster. Usually, the clusters are represented on the $y$-axis and the similarity or the distance is depicted on the $x$-axis. The lines that depart from each cluster are linked according to the degree of similarity at which the linkage between clusters happens. The obtained results from separate analyses provide homogeneous socio-economic and ecological units. The socio-economic and ecological units were layered and stored in a fishnet of $250 \mathrm{~m}$ grid size. The grid was clustered using the HCA to determine the boundaries of the SESs. For characterization of the mapped SESs, variable contribution in each socio-economic and ecological unit was determined using the variable loadings of the respective PCA. Prominent variables were selected as characteristic features of the SESs. The nomenclature for the SESs was derived using feedback on characteristics from domain experts such as scientists and environmental managers working in the Himalaya through discussions and informal meetings. The feedback helped in the nomenclature and characterization of the SESs.

\section{Results}

\subsection{Socio-Economic Units}

The KMO test result gave a value of 0.82 , and Bartlett's test of sphericity showed $p<2.22 \times 10^{-16}$ for the socio-economic variables. Socio-economic data were accounted for by the first nine PCs with $51.62 \%$ of the variability. Performing HCA on these components 
generated six socio-economic cluster units based on the common grouping of characteristics as illustrated in Figure 3. The distribution of eigenvalues and variability explained by each PCA component is presented in Appendix A (Table A3).
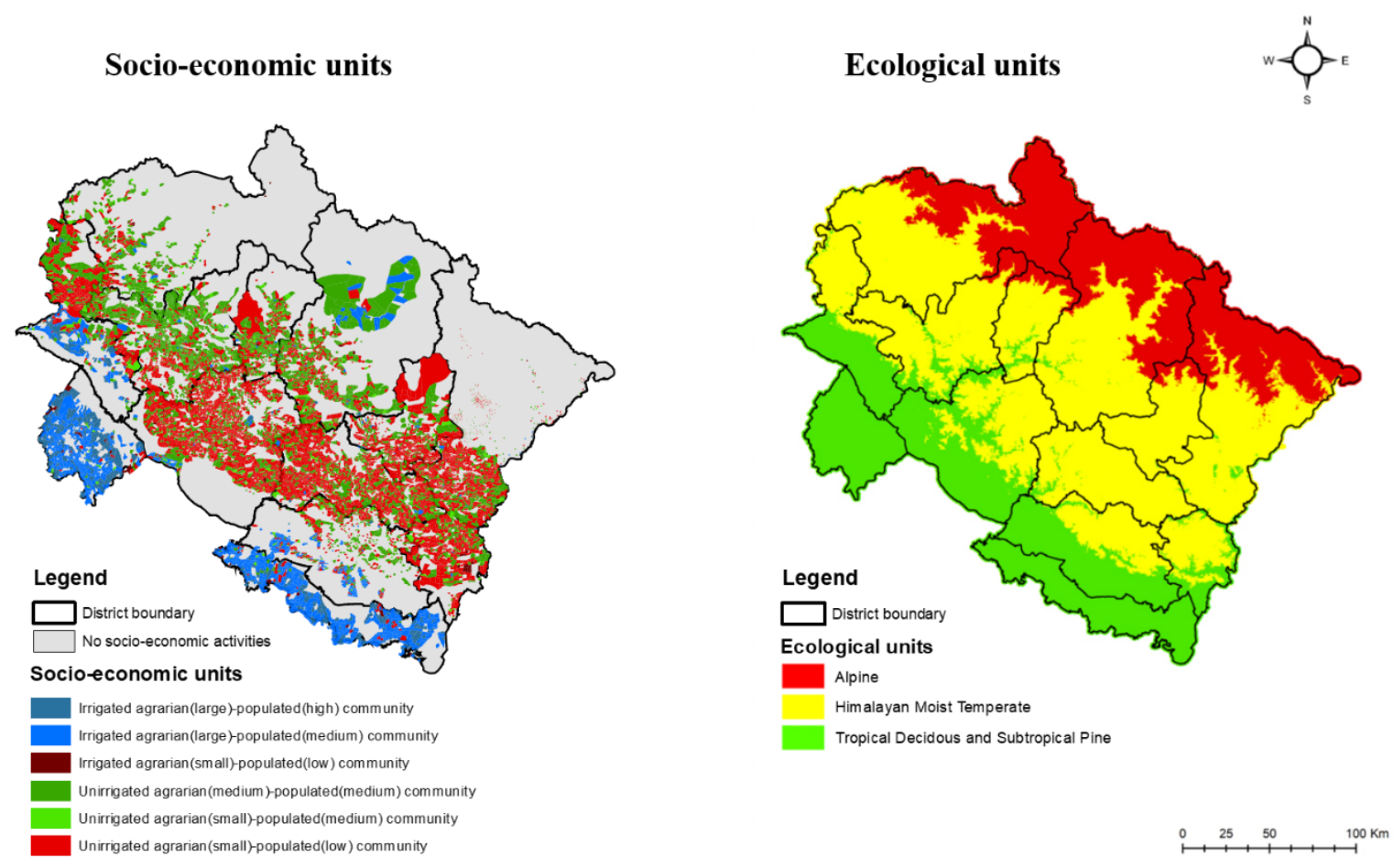

Figure 3. Socio-economic and ecological units of the Uttarakhand state. Six types of socio-economic and three types of ecological units were identified through the analysis.

Based on the variable loading for each cluster (Table 3), dominant characterizing features were used for the naming of the units (Table 4). The categorization of these features is presented in Appendix A (Table A4). For instance, Unit 1 (irrigated agrarian (large)-populated (high) community) represents the villages that are large and have well-irrigated land for agriculture. This unit occurs mostly in the plains at the foothills of the Himalaya known as Tarai and Bhabar, covering 1.82 percent of the geographical area. Unit 2 (irrigated agrarian (large)-populated (medium) community) represents the villages that have irrigated land and are modest in size. This unit is mostly present in the lower Himalaya and the valleys of the upper Himalaya covering together 8.82 percent of Uttarakhand. Unit 3 (irrigated agrarian (small)-populated (low) community) represents the villages that have a high population with unirrigated land for agriculture. This unit is distributed in the middle Himalayan region within the elevation range of 1000-2500 m, covering 31.72 percent of the land, thus, being the second-largest unit. Unit 4 (unirrigated agrarian (medium)-populated (medium) community) represents the villages that are small in area and have unirrigated land for agriculture. It is distributed throughout the middle Himalaya covering 4 percent of the area. Unit 5 (unirrigated agrarian (small)-populated (medium) community) represents the small villages, with a high population and unirrigated land for agriculture. It is distributed in the middle and upper Himalaya. It is the dominant unit covering 53.07 percent of the land in the state. Unit 6 (unirrigated agrarian (small)-populated (low) community) represents the villages that have irrigated land with better road connectivity and communication infrastructure. It is the smallest unit covering only 0.51 percent of land and is scattered throughout the Himalaya. In most of the cluster types, agriculture, geographical area, and population were the main epicenters around which the socio-economic strata reforms. 
Table 3. Major variable contribution in the socio-economic unit clustering from units 1 to 6; and in the ecological unit clustering from units A to C. See Figure A1 in Appendix A for full variable loadings.

\begin{tabular}{|c|c|c|c|}
\hline Type & Unit & Major Variable Contributor & Variable Loading \\
\hline \multirow{6}{*}{ Socio-economic units } & 1 & $\begin{array}{c}\text { Total geographical area (G_area); Net area sown (Nt_swn); Area } \\
\text { irrigated by source (Irrigt) }\end{array}$ & $>12$ \\
\hline & 2 & Area irrigated by source (Irrigt); Net area sown (Nt_swn) & $\geq 14$ \\
\hline & 3 & Net area sown (Nt_swn); Total households (Hshld) & $>12$ \\
\hline & 4 & $\begin{array}{c}\text { Total geographical area (G_area); Total households (Hshld); Total } \\
\text { unirrigated land area (Unirrgt); Net area sown (Nt_swn) }\end{array}$ & $\geq 10$ \\
\hline & 5 & $\begin{array}{c}\text { Total geographical area (G_area); Total households (Hshld); Net } \\
\text { area sown (Nt_swn) }\end{array}$ & $>10$ \\
\hline & 6 & $\begin{array}{c}\text { Area irrigated by source (Irrigt); Communication (Comm); } \\
\text { Transportation (Trnsprt) }\end{array}$ & $>10$ \\
\hline \multirow{3}{*}{ Ecological units } & A & $\begin{array}{c}\text { Forest types (Frst); Land use/Land cover (LULC); Soil type (Soil); } \\
\text { Isothermality (B3) }\end{array}$ & $>10$ \\
\hline & $\mathrm{B}$ & $\begin{array}{c}\text { Forest types (Frst); Land use/Land cover (LULC); } \\
\text { Isothermality (B3) }\end{array}$ & $>10$ \\
\hline & $\mathrm{C}$ & $\begin{array}{l}\text { Forest types (Frst); Land use/Land cover (LULC); Precipitation of } \\
\text { driest month (B14); Precipitation of driest quarter (B17) }\end{array}$ & $\geq 9$ \\
\hline
\end{tabular}

Table 4. Characterization of socio-economic units and ecological units.

\begin{tabular}{|c|c|c|c|c|c|}
\hline & Cluster & $\begin{array}{l}\text { No. of } \\
\text { Villages/ } \\
\text { Grids }\end{array}$ & Area $(\%)$ & Unit Description & Code \\
\hline \multirow{6}{*}{$\begin{array}{l}\text { Socio- } \\
\text { economic } \\
\text { units }\end{array}$} & 1 & 278 & 1.82 & Irrigated agrarian (large)-populated (high) community & 1 \\
\hline & 2 & 1357 & 8.88 & Irrigated agrarian (large)-populated (medium) community & 2 \\
\hline & 3 & 78 & 0.51 & Irrigated agrarian (small)-populated (low) community & 3 \\
\hline & 4 & 4849 & 31.72 & Unirrigated agrarian (medium)-populated (medium) community & 4 \\
\hline & 5 & 611 & 4.00 & Unirrigated agrarian (small)-populated (medium) community & 5 \\
\hline & 6 & 8112 & 53.07 & Unirrigated agrarian (small)-populated (low) community & 6 \\
\hline \multirow{3}{*}{$\begin{array}{l}\text { Ecological } \\
\text { units }\end{array}$} & 1 & 173,244 & 20.95 & Alpine & A \\
\hline & 2 & 437,384 & 52.89 & Himalayan moist temperate & B \\
\hline & 3 & 216,397 & 26.16 & Tropical deciduous and subtropical pine & $\mathrm{C}$ \\
\hline
\end{tabular}

\subsection{Ecological Units}

For the ecological variables, the KMO test result gave a value of 0.65 , and Bartlett's test of sphericity showed $p<2.22 \times 10^{-16}$. The distribution of eigenvalues and variability of PCA components is presented in Appendix A (Table A5). In Uttarakhand state, the HCA identified three ecological units illustrated in Figure 3. Based on the variable loadings of cluster units (Table 3), forest types and land use land cover (LULC) classes were identified as the characterizing feature (Table 4). Unit 1 (alpine) represents the alpine-dominated forest group in the state. It covers 20.95 percent of the state area in the upper Himalaya ( $>2500 \mathrm{~m}$ ). Unit 2 (Himalayan moist temperate) represents the Himalayan moist temperate forest group and is the largest unit in the state by covering 52.89 percent of the land area. This unit occurs in the middle Himalaya (1000-2500 m). Unit 3 (tropical deciduous and subtropical pine) covers 26.16 percent of the land and occurs in the lower and outer Himalaya $(<1000 \mathrm{~m})$.

\subsection{Socio-Ecological Systems}

The intersection of borders of socio-economic and ecological units determined the SES boundaries. After the delineation, 18 SES classes were generated and identified as shown in Figure 4 (see also Table 5). The key socio-economic and ecological characteristics were selected based on the methodological approach defining SESs in the Himalayan state. The 
major contributing ecological variable was identified as forest types and the most important socio-economic variable was agricultural practices. These two variables were determinant factors to characterize the generated 18 types of SESs (Table 3). The alpine-forest-based SESs are situated in the upper Himalayan region covering 21.71 percent of the land area, and the majority of this is covered with snow throughout the year. The Himalayan moist temperate forest-based SESs are situated in the middle Himalaya and are the major groups in the state covering 52.29 percent of the state area. Tropical deciduous and subtropical pine-based SESs are situated in the foothills and lower Himalaya covering 26 percent of the land area.

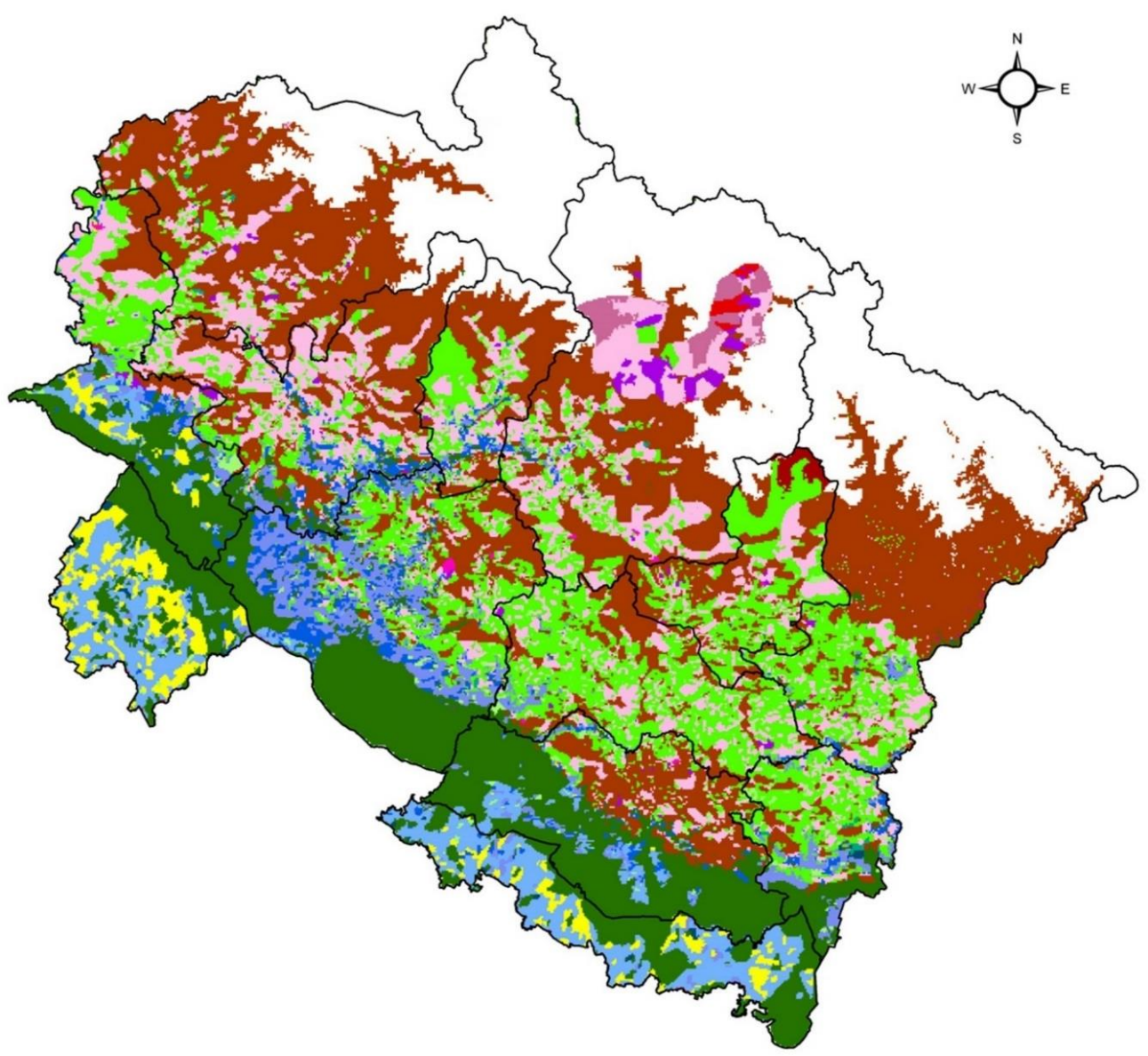

Legend

District boundary

Socio-Ecological Systems (SESs)

Alpine/Unirrigated agrarian(medium)-populated(medium) community

Alpine/Unirrigated agrarian(small)-populated(low) community

Alpine/Irrigated agrarian(large)-populated(high)community

Alpine/No village community

Himalayan Moist Temperate/Unirrigated agrarian(medium)-populated(medium) community

Himalayan Moist Temperate/Unirrigated agrarian(small)-populated(low) community

Himalayan Moist Temperate/Irrigated agrarian(large)-populated(medium) community

Himalayan Moist Temperate/Irrigated agrarian(large)-populated(high)community

Himalayan Moist Temperate/Irrigated agrarian(small)-populated(low) community

Himalayan Moist Temperate/No village community

Himalayan Moist Temperate/Unirrigated agrarian(small)-populated(medium) community

Tropical Deciduous and Subtropical Pine/Unirrigated agrarian(medium)-populated(medium) community

Tropical Deciduous and Subtropical Pine/Unirrigated agrarian(small)-populated(low) community

Tropical Deciduous and Subtropical Pine/Irrigated agrarian(large)-populated(medium) community

Tropical Deciduous and Subtropical Pine/Irrigated agrarian(large)-populated(high)community

Tropical Deciduous and Subtropical Pine/Irrigated agrarian(small)-populated(low) community

Tropical Deciduous and Subtropical Pine/No village community

Tropical Deciduous and Subtropical Pine/Unirrigated agrarian(small)-populated(medium) community

Figure 4. Spatial distribution of socio-ecological systems in Uttarakhand state. 
Table 5. Characterization of the socio-ecological systems.

\begin{tabular}{|c|c|c|c|}
\hline S. No. & Socio-Ecological System Description & Code & Area $(\%)$ \\
\hline 1 & $\begin{array}{l}\text { Alpine/Unirrigated agrarian (medium)-populated (medium) } \\
\text { community }\end{array}$ & A4 & 0.63 \\
\hline 2 & Alpine/Unirrigated agrarian (small)-populated (low) community & A6 & 0.22 \\
\hline 3 & Alpine/Irrigated agrarian (large)-populated (high) community & $\mathrm{A} 2$ & 0.2 \\
\hline 4 & Alpine/No village community & A0 & 20.66 \\
\hline 5 & $\begin{array}{l}\text { Himalayan moist temperate/Unirrigated agrarian } \\
\text { (medium)-populated (medium) community }\end{array}$ & $\mathrm{B} 4$ & 11.55 \\
\hline 6 & $\begin{array}{l}\text { Himalayan moist temperate/Unirrigated agrarian (small)-populated } \\
\text { (low) community }\end{array}$ & B6 & 13.38 \\
\hline 7 & $\begin{array}{l}\text { Himalayan moist temperate/Irrigated agrarian (large)-populated } \\
\text { (medium) community }\end{array}$ & B2 & 0.6 \\
\hline 8 & $\begin{array}{l}\text { Himalayan moist temperate/Irrigated agrarian (large)-populated } \\
\text { (high) community }\end{array}$ & B1 & 0.08 \\
\hline 9 & $\begin{array}{l}\text { Himalayan moist temperate/Irrigated agrarian (small)-populated } \\
\text { (low) community }\end{array}$ & B3 & 0.1 \\
\hline 10 & Himalayan moist temperate/No village community & B0 & 25.46 \\
\hline 11 & $\begin{array}{l}\text { Himalayan moist temperate/Unirrigated agrarian (small)-populated } \\
\text { (medium) community }\end{array}$ & B5 & 1.13 \\
\hline 12 & $\begin{array}{l}\text { Tropical deciduous and subtropical pine/Unirrigated agrarian } \\
\text { (medium)-populated (medium) community }\end{array}$ & $\mathrm{C} 4$ & 1.91 \\
\hline 13 & $\begin{array}{l}\text { Tropical deciduous and subtropical pine/Unirrigated agrarian } \\
\text { (small)-populated (low) community }\end{array}$ & C6 & 3.71 \\
\hline 14 & $\begin{array}{l}\text { Tropical deciduous and subtropical pine/Irrigated agrarian } \\
\text { (large)-populated (medium) community }\end{array}$ & $\mathrm{C} 2$ & 4.51 \\
\hline 15 & $\begin{array}{l}\text { Tropical deciduous and subtropical pine/Irrigated agrarian } \\
\text { (large)-populated (high) community }\end{array}$ & $\mathrm{C} 1$ & 1.99 \\
\hline 16 & $\begin{array}{l}\text { Tropical deciduous and subtropical pine/Irrigated agrarian } \\
\text { (small)-populated (low) community }\end{array}$ & $\mathrm{C} 3$ & 0.14 \\
\hline 17 & Tropical deciduous and subtropical pine/No village community & $\mathrm{CO}$ & 13.40 \\
\hline 18 & $\begin{array}{l}\text { Tropical deciduous and subtropical pine/Unirrigated agrarian } \\
\text { (small)-populated (medium) community }\end{array}$ & C5 & 0.34 \\
\hline
\end{tabular}

The Himalayan moist temperate/unirrigated agrarian (small)-populated (low) community (B6) within the middle Himalaya is the major socio-ecological system with $13.38 \%$ cover in the state. This system has small villages with low farm holdings in a temperate climate. The other major system is the Himalayan moist temperate/unirrigated agrarian (medium)-populated (medium) community (B4) covering $11.55 \%$ in the middle Himalaya. In this system, the villages have a moderate population linked with a temperate climate. These two systems with temperate climate are located in the middle Himalaya. The villages are sparsely populated and have mostly unirrigated agriculture, making the communities highly dependent on forest resources due to the geographical setting of the region. In the lower Himalaya, the major SESs are the tropical deciduous and subtropical pine/irrigated agrarian (large)-populated (medium) community (C2) with $4.51 \%$ and the tropical deciduous and subtropical pine/unirrigated agrarian (small)-populated (low) community (C6) with $3.71 \%$.

The spatial mapping shows two pertinent aspects of the Himalaya, the ecosystem and the society. Our mapping highlights the interactions and linkages between the ecological subsystems and social systems (Figure 5). The alpine ecological unit is dominated by social systems with large-to-medium irrigated land and medium population density (A2, A4, and A6). These are more in the high altitudes of the mountain systems. The Himalayan moist temperate forest shows a much wider range of linkages across the social units of the region. These are dominated by villages with low-to-medium population with unirrigated agrarian practices (B1, B2, B3, B4, B5, and B6). However, it also supports other social units. These ecological systems range from low-to-medium altitude with select pockets in high-altitude regions. The tropical deciduous and subtropical pine forests also share a wider linkage 
across all the social units of the Central Himalaya. These exhibit a stronger linkage with irrigated large agrarian-medium population communities (C1, C2, C3, C4, C5, and C6). Unlike the Himalayan moist temperate forest, these do not have a wider distribution and are restricted much to lower altitudes and a few ranges of middle altitude.

A
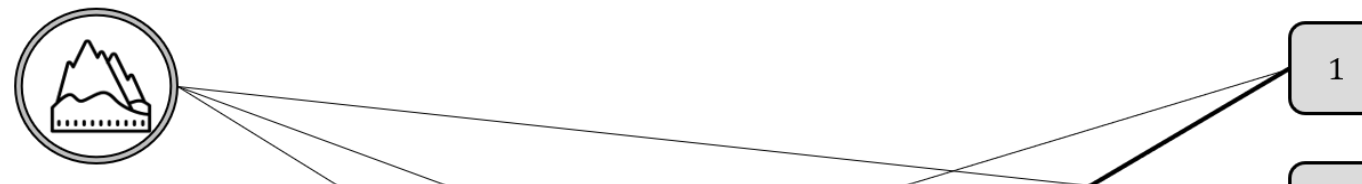

B
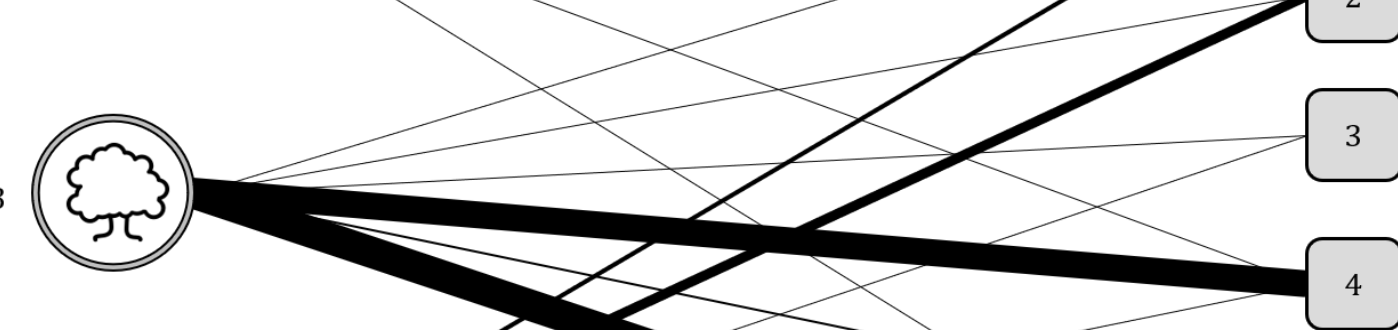

C

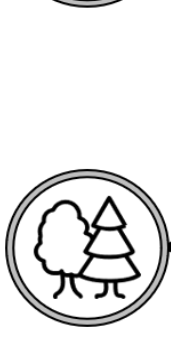

Ecological units

Socio-economic units

A - Alpine

B - Himalayan moist temperate

C - Tropical deciduous and subtropical pine
1 - Irrigated agrarian (large)-populated (high) community

2 - Irrigated agrarian (large)-populated (medium) community

3 - Irrigated agrarian (small)-populated (low) community

4 - Unirrigated agrarian (medium)-populated (medium) community

5 - Unirrigated agrarian (small)-populated (medium) community

6 - Unirrigated agrarian (small)-populated (low) community

Figure 5. The linkage between the ecological units and socio-economic units based on their association. The width of the linkage represents the magnitude of the interaction between the units.

\section{Discussion}

Identification and spatial mapping of SESs at the regional level is demanding since administrative borders often do not coincide with natural variables that determine how nature is managed by people. Therefore, an interdisciplinary approach is required that supports integrating a wide range of variables considering social and ecological interactions. Most of the earlier studies $[1,5,10,11,22]$ have mapped these for a smaller geographical area (e.g., regional, municipality, national park) or with a focus on particular system types. Martín-López et al. [1] identified SESs at a local level to understand the interaction at the local level, which can be useful for meta-analysis of the individual SESs. In addition to the understanding of the cross-disciplinary approaches, the geospatial tools and data integration capability have enhanced opportunities to analyze potential and complex relationships and interactions between social and ecological systems [64,65]. Researchers have leveraged such capabilities to identify and map different ecological units [66-68]. The identification and spatial mapping of SESs in the Central Himalaya presented in this study is one of the first attempts to develop an indicator-based model. It extends previous efforts of mapping SESs $[1,11,22]$, in that it takes a broader range of both social and ecological variables into account. Such an attempt has multiple advantages and a few limitations, 
which can assist researchers to replicate, reproduce, and enhance it over time to identify changes in social-ecological systems, essential to policy planning [22].

These intricate linkages between the ecological and social systems indicate the distinct vulnerability and adaptive capacities of the communities to climate change. The relationships also explain the dependence of the socio-economic units on the ecological units, indicating higher dependence on forests. For example, Himalayan moist temperate forests are known for the resource utilization structures, processes, and patterns in the region, and thus these are highly associated with the forests, farmland, and livestock [69,70]. Similarly, the dependence is higher on the tropical deciduous and subtropical pine forest and the least on the alpine ecological units. Such relationships also indicate the services and support rendered by these ecological units to the socio-economic units in the Central Himalaya. These provide multiple ecosystem services including much of the supporting and regulating services for such communities, e.g., biomass production, soil formation and retention, nutrient cycling, provisioning of habitat, and regulation of climate and water [71].

\subsection{Advancement in Methods}

The presented methodological framework combines the multivariate analysis of both biophysical and socio-economic variables using GIS to identify and characterize the SESs [1] The study generated SESs at the regional level with characteristics features though the SESs are nested at multiple spatial levels [3]. The modified methodology has similar limitations that have been noted by others in their studies [1,22,72]. Few of the variables' data were not available at the local level in the study, so that they had to be downscaled, and this increased the data-borne uncertainty of the mapping exercise [73]. Our analysis suggests that there is a need to carefully consider scale to generate SES units. Analyses at multiple spatial scales will reveal different patterns of complexity and dynamics, thus, limiting the recognition of the complex dynamics of SESs. Our approach is limited by the availability of data. For example, factors responsible for governance are not included in the approach [6]. In order to interpret large datasets, methods are required to drastically reduce their dimensionality in an interpretable way, such that most of the information in the data is preserved. It gives the best possible representation of a $p$-dimensional dataset in $q$ dimensions $(q<p)$ in the sense of maximizing variance in q dimensions. A disadvantage is, however, that the new variables that it defines are usually linear functions of all $\mathrm{p}$ original variables, and there is a trade-off between interpretability and variance [74]. In this study, since the original random variables are non-Gaussian distributed, their linear combinations were non-Gaussian distributed, and uncorrelated principal components were independent. The removal of outliers does create a normal distribution in some of the variables, but for some variables, outliers are informative about the subject area and data collection process, which was essential in the study to understand the spatial complexity.

The framework helps in replacing the general administrative boundary criteria used in adaptation and landscape planning using a socio-ecological approach. From a social scientific point of view, the boundaries on a map do not correspond with the association of the physical and social world [75]. The perceived boundaries of SESs can vary among actors considering their landscape-scale usage patterns [1]. Cross-scale modeling concepts have emerged in landscape ecology as a way to better capture complex system characteristics to support science and practitioner interactions [76]. These abstractions of the real-world address different types of governance, how resources are influenced, and how human action or behavior affects the ecosystem's performance [77].

\subsection{Relevance and Applicability of the Method}

This study provides a robust methodology to delineate and characterize SESs, which could be adopted in the entire Himalayan arc and in other mountain ecosystems of the world. Mapped SESs can provide a basic template for studies in mountain ecosystems related to climate change impacts, vulnerability assessment, adaptation planning, risk and 
hazards assessment, the resilience of communities to multiple stressors, natural resource management, and policy- and decision-making. Characterizing multilevel interactions from local communities to national decision-makers encourages robust policy-making to ensure sustainable resource management [78]. Combining practitioners' knowledge with socio-economic and environmental changes in modeling platforms acts as a vehicle toward proactive spatial assessment and planning. Pivotal for policy-making is a better recognition of cross-disciplinary models to ensure information and communication flows for developing landscape as well as adaptation planning strategies [79]. The mapped SESs help in recognizing local needs and gaps in existing policies and institutional arrangements. Taking SES as a coupled system will help policymakers to look at two fronts as a single unit. Beyond these practicum usages, the study fills a wide gap in SES approaches for vulnerability assessment in mountain ecosystems as it considers the differences and associations of socio-economic and ecological system characteristics and acts as a tool for policy implementation to reduce vulnerability [80]. This would pave the pathways for future academic and research-based studies. Understanding the SESs can help in explaining the natural resource usage pattern by the communities of socio-economic units and major ecosystem services. Homogenous ecological units have similar kinds of services and usage patterns. This helps in analyzing and modeling SES interactions to better understand feedback, non-linearity, and the future dynamics of drivers across multiple scales [81].

\subsection{Outlook}

India is classified into 15 agroclimatic zones by the National Bureau of Soil Survey and Land Use Planning (NBSS\&LUP). These zones are classified based on climatic factors, soil properties, physiographic settings, geological formation, climate, cropping patterns, and development of irrigation and mineral resources. Uttarakhand state is classified as a Western Himalayan agroclimatic zone. It is further divided into two subclasses, namely Hill (AZ26) and Bhabar and Tarai (AZ27). Our approach identified seven different types of SESs in the Bhabar and Tarai (AZ27) zone and eleven types of SESs in the Hill (AZ26) zone with distinct features providing more details for planning. Agroclimatic zonation and other similar approaches such as biome [66] and bio-geographical zone [82] mapping mainly address ecological settings but do not take into account the association of communities and institutions. To our knowledge, this is the first time that census data on resource use have been used to identify and map SESs in the Himalayan landscape. Therefore, the developed database and method can be used as a tool for locally adapted actors and institutions for efficient planning and management. The studied cases of Uttarakhand state showed that there is a need for locally suitable adaptation planning and management to avoid a one size fits all strategy $[17,83]$ in social and ecological aspects. The SESs provide variation and specific features pertinent to the interlinked network of resource systems and actors [6].

A study by Dressel et al. [22] used PCA on multiple socio-ecological variables to understand the socio-ecological context of natural resource management. Martín-López et al. [1] identified SES boundaries to explain their importance in landscape planning for managing ecosystem services. Our approach used a similar principle but focused on characterizing a larger geographical entity in mountain systems to provide SESs boundaries and improve the understanding of the characteristics that define the SESs.

\section{Conclusions}

The study has demonstrated an approach to identify and spatially map socio-ecological systems in the Central Himalaya. It developed an indicator-based model on an understanding of the intricate relationship between social systems and ecological systems and by explaining the characteristic features over a large heterogeneous area. This is the first time that census data on resource and biophysical variables on ecological distribution area were used to identify and map SESs in the Himalayan region. The approach differs from earlier attempts at mapping ecological units and linking with social data to describe the socio-ecological system. The SESs mapping will help in improving the currently practiced 
mapping approach in the Himalayan region for socio-economic and ecological planning and management. The approach presented here may be a practical tool that can be replicated and reproduced across mountain ecosystems. The subsequent understandings will, therefore, support the preparation of adaptation plans to cope with the impacts of climate change in the Himalayan region and sustainable natural resource management. Our approach is a beneficial tool to analyze and represent the multidimensional systems of mountainous regions to help decision- and policymakers develop site-specific policies. The future challenges in SES research involve the understanding of dynamics at multiple scales and the development of credible measures of evaluation, corporate governance, and promotion of adaptation. To understand the complexity of the SESs, a further meta-analysis by integrating participatory methods for each system is necessary. Overall, a rigorous and in-depth approach is necessary to combat these situations.

Author Contributions: Conceptualization, P.K.J. and P.K.; methodology, P.K. and P.K.J.; software, P.K. and C.F.; validation, P.K. and P.K.J.; formal analysis, P.K.; investigation, P.K.J. and P.K.; resources, P.K.J. and C.F.; data curation, P.K.; writing — original draft preparation, P.K.; writing—review and editing, P.K., P.K.J., and C.F.; visualization, P.K.J. and P.K.; supervision, P.K.J. and C.F.; project administration, P.K.J.; funding acquisition, C.F. All authors have read and agreed to the published version of the manuscript.

Funding: P.K. would like to acknowledge a UGC-JRF scholarship by the University Grants Commission, Ministry of Human Resource Development, Government of India; and a DAAD scholarship, Federal government of Germany, for funding his doctoral research.

Data Availability Statement: The data presented in this study are available in this article.

Acknowledgments: The authors would like to acknowledge the Institute for Geosciences and Geography at Martin Luther University, Halle, Germany, for their support in providing a highperformance computing facility for data analysis. Authors are also thankful to the reviewers and editorial board for comments and advice to improve the quality of manuscript.

Conflicts of Interest: The authors declare no conflict of interest. The funders had no role in the design of the study; in the collection, analyses, or interpretation of data; in the writing of the manuscript; or in the decision to publish the results.

\section{Appendix A}

Table A1. List of total variables used to form ecological units.

\begin{tabular}{llll}
\hline Type & Variable Name & Code & Data Source \\
\hline Climatic & Climatic Annual Mean Temperature & BIO 1 & WorldClim \\
& Mean Diurnal Range & BIO 2 & WorldClim \\
Isothermality (BIO 2/BIO 7) $(\times 100)$ & BIO 3 & WorldClim \\
Temperature Seasonality (Standard Deviation $\times 100)$ & BIO 4 & WorldClim \\
Max. Temperature of Warmest Month & BIO 5 & WorldClim \\
Min. Temperature of Coldest Month & BIO 6 & WorldClim \\
Temperature Annual Range (BIO 5-BIO 6) & BIO 7 & WorldClim \\
Mean Temperature of Wettest Quarter & BIO 8 & WorldClim \\
Mean Temperature of Driest Quarter & BIO 9 & WorldClim \\
Mean Temperature of Warmest Quarter & BIO 10 & WorldClim \\
Mean Temperature of Coldest Quarter & BIO 11 & WorldClim \\
Annual Precipitation & BIO 12 & WorldClim \\
Precipitation of Wettest Month & BIO 13 & WorldClim \\
Precipitation of Driest Month & BIO 14 & WorldClim \\
\hline
\end{tabular}


Table A1. Cont.

\begin{tabular}{llll}
\hline Type & Variable Name & Code & Data Source \\
\hline & Precipitation Seasonality (Coefficient of Variation) & BIO 15 & WorldClim \\
& Precipitation of Wettest Quarter & BIO 16 & WorldClim \\
& Precipitation of Driest Quarter & BIO 17 & WorldClim \\
& Precipitation of Warmest Quarter & BIO 18 & WorldClim \\
& Precipitation of Coldest Quarter & BIO 19 & WorldClim \\
Geomorphologic & Elevation & Elv & ASTER-GDEM \\
& Aspect & Asp & ASTER-GDEM \\
& Slope & Slp & ASTER-GDEM \\
Pedologic & Soil type & Soil & National Bureau of Soil \\
Land use/Land & & & Survey and Land Use \\
cover & LULC & LULC & National Remote Sensing \\
Forest Cover & Forest Types & Frst & Fenter \\
Biophysical & Normalized Difference Vegetation Index & NDVI & MODIS \\
& Enhanced Vegetation Index & EVI & MODIS \\
& Normalized Difference Water Index & NDWI & MODIS \\
\hline
\end{tabular}

Table A2. List of total variables used to form socio-economic units (source: Census of India, 2011).

\begin{tabular}{|c|c|c|c|c|c|}
\hline Type & & & Variables & & \\
\hline Demographics & $\begin{array}{l}\text { Total Geographical Area } \\
\text { (in Hectares) }\end{array}$ & Total Households & $\begin{array}{l}\text { Total Population of } \\
\text { Village }\end{array}$ & & \multirow{15}{*}{$\begin{array}{l}\text { Family } \\
\text { Welfare } \\
\text { Center }\end{array}$} \\
\hline $\begin{array}{l}\text { Primary Education } \\
\text { (Numbers) }\end{array}$ & $\begin{array}{l}\text { Govt. Preprimary School } \\
\text { (Nursery/LKG/UKG) }\end{array}$ & $\begin{array}{l}\text { Private Preprimary } \\
\text { School (Nurs- } \\
\text { ery/LKG/UKG) }\end{array}$ & $\begin{array}{l}\text { Govt. Primary } \\
\text { School }\end{array}$ & $\begin{array}{l}\text { Private Primary } \\
\text { School }\end{array}$ & \\
\hline $\begin{array}{l}\text { Secondary School } \\
\text { (Numbers) }\end{array}$ & $\begin{array}{l}\text { Govt. Middle School } \\
\text { Govt. Senior Secondary } \\
\text { School }\end{array}$ & $\begin{array}{l}\text { Private Middle } \\
\text { School } \\
\text { Private Senior } \\
\text { Secondary School }\end{array}$ & $\begin{array}{l}\text { Govt. Secondary } \\
\text { School }\end{array}$ & $\begin{array}{l}\text { Private Secondary } \\
\text { School }\end{array}$ & \\
\hline $\begin{array}{l}\text { Higher Education } \\
\text { (Numbers) }\end{array}$ & $\begin{array}{l}\text { Govt. Arts and Science } \\
\text { Degree College } \\
\text { Govt. Medical College }\end{array}$ & $\begin{array}{l}\text { Private Arts and } \\
\text { Science Degree } \\
\text { College } \\
\text { Private Medical } \\
\text { College }\end{array}$ & $\begin{array}{l}\text { Govt. Engineering } \\
\text { College }\end{array}$ & $\begin{array}{l}\text { Private Engineering } \\
\text { College }\end{array}$ & \\
\hline \multirow[t]{2}{*}{ Healthcare (Numbers) } & $\begin{array}{l}\text { Community Health } \\
\text { Center }\end{array}$ & $\begin{array}{l}\text { Primary Health } \\
\text { Center }\end{array}$ & $\begin{array}{l}\text { Primary Health } \\
\text { Subcenter }\end{array}$ & $\begin{array}{l}\text { Maternity And Child } \\
\text { Welfare Center }\end{array}$ & \\
\hline & Hospital_Allopathic & $\begin{array}{l}\text { Hospital- } \\
\text { Alternative } \\
\text { Medicine }\end{array}$ & Dispensary & Mobile Health Clinic & \\
\hline Toilet & $\begin{array}{l}\text { Toilet Complex } \\
\text { (including Bath) }\end{array}$ & & & & \\
\hline Tap Water & Tap Water-Treated & $\begin{array}{l}\text { Tap } \\
\text { Water-Untreated }\end{array}$ & & & \\
\hline $\begin{array}{l}\text { Well } \\
\text { Hand Pump/Tube Wells }\end{array}$ & $\begin{array}{l}\text { Covered Well } \\
\text { Hand Pump }\end{array}$ & $\begin{array}{l}\text { Uncovered Well } \\
\text { Tube Wells/Borehole }\end{array}$ & & & \\
\hline $\begin{array}{l}\text { River/Canal/Tank/ } \\
\text { Pond/Lake }\end{array}$ & River/Canal & Tank/Pond/Lake & Spring & & \\
\hline Post Office & Post Office & Sub-Post Office & $\begin{array}{l}\text { Post and Telegraph } \\
\text { Office }\end{array}$ & & \\
\hline Communication & $\begin{array}{l}\text { Public Call } \\
\text { Office/Mobile (PCO) }\end{array}$ & $\begin{array}{l}\text { Mobile Phone } \\
\text { Coverage }\end{array}$ & $\begin{array}{l}\text { Internet } \\
\text { Cafes/Common } \\
\text { Service Center (CSC) }\end{array}$ & Telephone & \\
\hline Transportation & Public Bus Service & Private Bus Service & Railway Station & $\begin{array}{l}\text { Auto/Modified } \\
\text { Autos }\end{array}$ & \\
\hline Road Connectivity & $\begin{array}{l}\text { Black Topped (pakka) } \\
\text { Road } \\
\text { All-Weather Road }\end{array}$ & $\begin{array}{l}\text { Gravel (kuchha) } \\
\text { Roads } \\
\text { State Highway }\end{array}$ & $\begin{array}{l}\text { Water-Bound } \\
\text { Macadam } \\
\text { National Highway }\end{array}$ & & \\
\hline $\begin{array}{l}\text { Bank Services } \\
\text { Credit Societies }\end{array}$ & $\begin{array}{l}\text { ATM } \\
\text { Agricultural Credit } \\
\text { Societies }\end{array}$ & $\begin{array}{l}\text { Commercial Bank } \\
\text { Self-Help Group } \\
\text { (SHG) }\end{array}$ & Cooperative Bank & & \\
\hline
\end{tabular}


Table A2. Cont.

\begin{tabular}{|c|c|c|c|c|}
\hline Type & & & Variables & \\
\hline Market & Mandis/Regular Market & Weekly Haat & $\begin{array}{l}\text { Public Distribution } \\
\text { System (PDS) Shop }\end{array}$ & \\
\hline Govt. Health Program & $\begin{array}{l}\text { Nutritional } \\
\text { Centers-Anganwadi } \\
\text { Center }\end{array}$ & ASHA & & \\
\hline Waste Disposal & $\begin{array}{l}\text { Waste Disposal System } \\
\text { after House-to-House } \\
\text { Collection }\end{array}$ & $\begin{array}{l}\text { Bio-gas or Recycling } \\
\text { of Waste for } \\
\text { Production Use }\end{array}$ & & \\
\hline Media & $\begin{array}{l}\text { Community Center } \\
\text { with/without TV }\end{array}$ & $\begin{array}{l}\text { Sports } \\
\text { Club/Recreation } \\
\text { Center }\end{array}$ & Cinema/Video Hall & \\
\hline Information & Public Library & $\begin{array}{l}\text { Public Reading } \\
\text { Room }\end{array}$ & $\begin{array}{l}\text { Daily Newspaper } \\
\text { Supply }\end{array}$ & $\begin{array}{l}\text { Assembly Polling } \\
\text { Station }\end{array}$ \\
\hline $\begin{array}{l}\text { Agriculture } \\
\text { Infrastructure }\end{array}$ & Agriculture Equipment & Tractors & $\begin{array}{l}\text { Carts Driven by } \\
\text { Animals }\end{array}$ & \\
\hline Electricity & $\begin{array}{l}\text { Power Supply for } \\
\text { Domestic Use }\end{array}$ & $\begin{array}{l}\text { Power Supply for } \\
\text { Agriculture Use }\end{array}$ & $\begin{array}{l}\text { Power Supply for } \\
\text { Commercial Use }\end{array}$ & \\
\hline Agricultural Land & $\begin{array}{l}\text { Culturable Waste Land } \\
\text { Area (in Hectares) }\end{array}$ & $\begin{array}{l}\text { Fallows Land other } \\
\text { than Current Fallows } \\
\text { Area (in Hectares) }\end{array}$ & $\begin{array}{l}\text { Current Fallows } \\
\text { Area (in Hectares) }\end{array}$ & \\
\hline \multirow{3}{*}{ Land } & $\begin{array}{l}\text { Net Area Sown (in } \\
\text { Hectares) }\end{array}$ & $\begin{array}{l}\text { Total Unirrigated } \\
\text { Land Area (in } \\
\text { Hectares) }\end{array}$ & $\begin{array}{l}\text { Area Irrigated by } \\
\text { Source (in Hectares) }\end{array}$ & \\
\hline & Forest Area (in Hectares) & $\begin{array}{l}\text { Area under } \\
\text { Non-Agricultural } \\
\text { Uses (in Hectares) }\end{array}$ & $\begin{array}{l}\text { Barren and } \\
\text { Un-cultivable Land } \\
\text { Area (in Hectares) }\end{array}$ & \\
\hline & $\begin{array}{l}\text { Permanent Pastures and } \\
\text { Other Grazing Land Area } \\
\text { (in Hectares) }\end{array}$ & $\begin{array}{l}\text { Land under } \\
\text { Miscellaneous Tree } \\
\text { Crops, etc., Area (in } \\
\text { Hectares) }\end{array}$ & & \\
\hline
\end{tabular}

Table A3. Distribution of eigenvalues and variability by PCA components for socio-economic units.

\begin{tabular}{cccc}
\hline Component & Eigenvalue & Percentage of Variance & Cumulative Percentage of Variance \\
\hline 1 & 5.0205182 & 16.19522 & 16.19522 \\
2 & 2.4833644 & 8.010853 & 24.20607 \\
3 & 1.5594366 & 5.030441 & 29.23651 \\
4 & 1.4401137 & 4.645528 & 33.88204 \\
5 & 1.1921083 & 3.845511 & 41.72755 \\
6 & 1.1492132 & 3.73469 \\
7 & 1.1019871 & 3.554797 & 44.98949 \\
8 & 1.0516104 & 3.392292 & 48.38178 \\
9 & 1.0066872 & 3.247378 & 51.62916 \\
10 & 0.9893615 & 3.191489 & 54.82065 \\
11 & 0.9703779 & 3.130251 & 57.9509 \\
12 & 0.9557607 & 3.083099 & 61.034 \\
13 & 0.9076826 & 2.928008 & 63.96201 \\
14 & 0.8888257 & 2.86718 & 66.82919 \\
15 & 0.8738607 & 2.818906 & 69.64809 \\
16 & 0.8603775 & 2.775411 & 72.4235 \\
17 & 0.8536764 & 2.753795 & 75.1773 \\
18 & 0.8078302 & 2.605904 & 77.7832 \\
19 & 0.7867955 & 2.53805 & 80.32125 \\
20 & 0.7492632 & 2.416978 & 82.73823 \\
21 & 0.699398 & 2.256123 & 84.99435 \\
22 & 0.6863401 & 2.214 & 87.20835 \\
23 & 0.6332295 & 2.042676 & 89.25103 \\
24 & 0.5855329 & 1.888816 & 91.13984 \\
\hline
\end{tabular}


Table A3. Cont.

\begin{tabular}{cccc}
\hline Component & Eigenvalue & Percentage of Variance & Cumulative Percentage of Variance \\
\hline 25 & 0.556595 & 1.795468 & 92.93531 \\
26 & 0.5209481 & 1.680478 & 94.61579 \\
27 & 0.4585095 & 1.479063 & 96.09485 \\
28 & 0.4205302 & 1.356549 & 97.4514 \\
29 & 0.4058192 & 1.309094 & 98.7605 \\
30 & 0.2451117 & 0.790683 & 99.55118 \\
31 & 0.1391345 & 0.448821 & 100 \\
\hline
\end{tabular}

Table A4. Categorization of the socio-economic units with their mean households and area per village.

\begin{tabular}{|c|c|c|c|c|c|}
\hline Socio-Economic Unit & $\begin{array}{l}\text { Number of } \\
\text { Villages }\end{array}$ & $\begin{array}{l}\text { Mean Area per } \\
\text { Village (in } \\
\text { Hectares) }\end{array}$ & $\begin{array}{c}\text { Large/Medium/ } \\
\text { Small }\end{array}$ & $\begin{array}{l}\text { Mean Households } \\
\text { per Village }\end{array}$ & High/Medium/Low \\
\hline $\begin{array}{l}\text { Irrigated agrarian } \\
\text { (large)-populated } \\
\text { (high) community }\end{array}$ & 278 & 452.3 & $\mathrm{~L}$ & 646 & $\mathrm{H}$ \\
\hline $\begin{array}{l}\text { Irrigated agrarian } \\
\text { (large)-populated } \\
\text { (medium) community }\end{array}$ & 1357 & 165.19 & $\mathrm{~L}$ & 188 & M \\
\hline $\begin{array}{l}\text { Irrigated agrarian } \\
\text { (small)-populated } \\
\text { (low) community }\end{array}$ & 78 & 85.23 & $S$ & 13 & $\mathrm{~L}$ \\
\hline $\begin{array}{l}\text { Unirrigated agrarian } \\
\text { (medium)-populated } \\
\text { (medium) community }\end{array}$ & 4849 & 104.79 & M & 74 & M \\
\hline $\begin{array}{l}\text { Unirrigated agrarian } \\
\text { (small)-populated } \\
\text { (medium) community }\end{array}$ & 611 & 79.6 & $\mathrm{~S}$ & 51 & M \\
\hline $\begin{array}{l}\text { Unirrigated agrarian } \\
\text { (small)-populated } \\
\text { (low) community }\end{array}$ & 8112 & 57.35 & $S$ & 27 & $\mathrm{~L}$ \\
\hline
\end{tabular}

Table A5. Distribution of eigenvalues and variability by PCA components for ecological units.

\begin{tabular}{cccc}
\hline Component & Eigenvalue & Percentage of Variance & Cumulative Percentage of Variance \\
\hline 1 & 4.8433 & 34.595 & 34.595 \\
2 & 3.37687 & 24.1205 & 58.7155 \\
3 & 1.59367 & 11.3834 & 70.0989 \\
4 & 1.00264 & 7.16174 & 77.2607 \\
5 & 0.83842 & 5.9887 & 83.2494 \\
6 & 0.7459 & 5.32784 & 88.5772 \\
7 & 0.57257 & 4.08978 & 92.667 \\
8 & 0.47321 & 3.38008 & 96.0471 \\
9 & 0.32444 & 2.31741 & 98.3645 \\
10 & 0.13174 & 0.94098 & 99.3054 \\
11 & 0.05924 & 0.42316 & 99.7286 \\
13 & 0.02881 & 0.20579 & 99.9344 \\
14 & 0.00758 & 0.05415 & 99.9886 \\
\hline
\end{tabular}




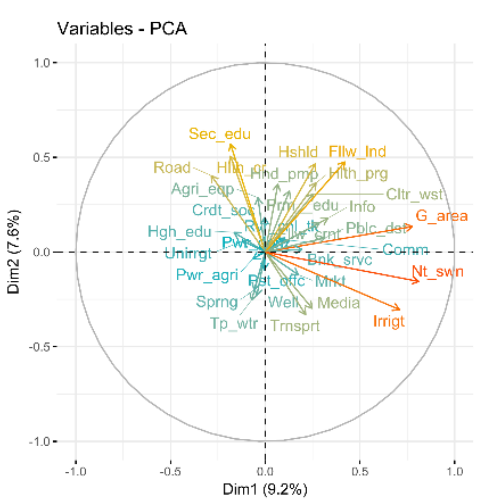

1

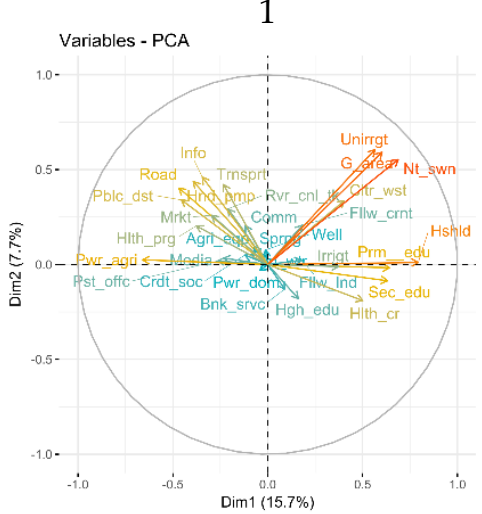

4

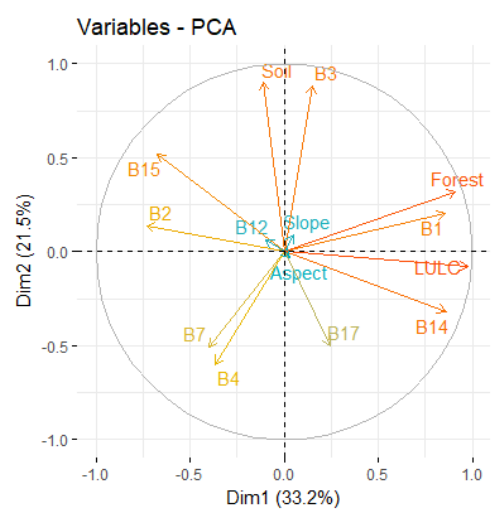

A

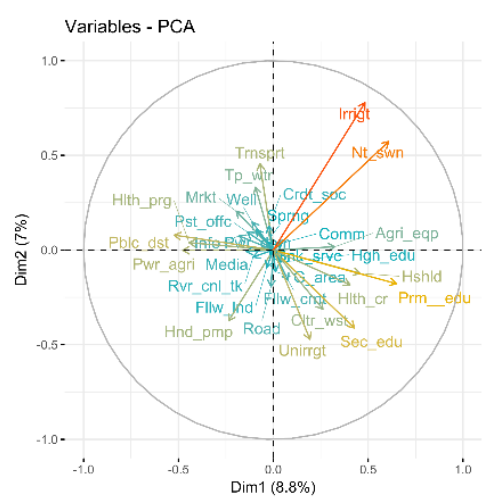

2

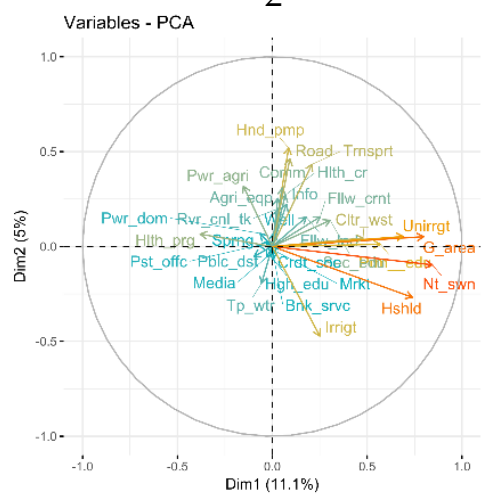

5

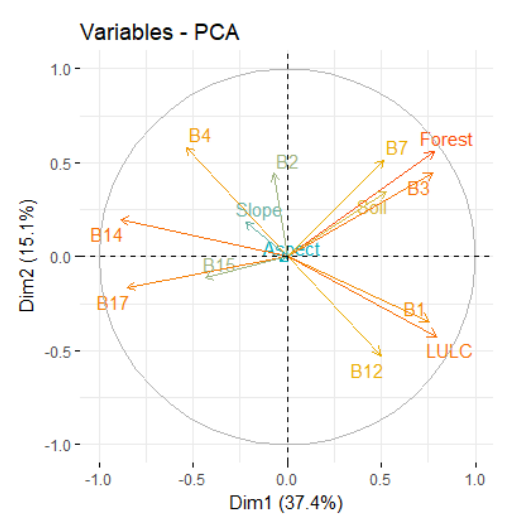

B

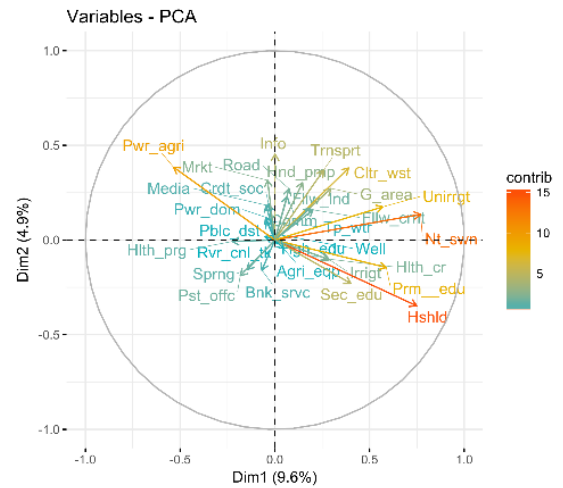

3

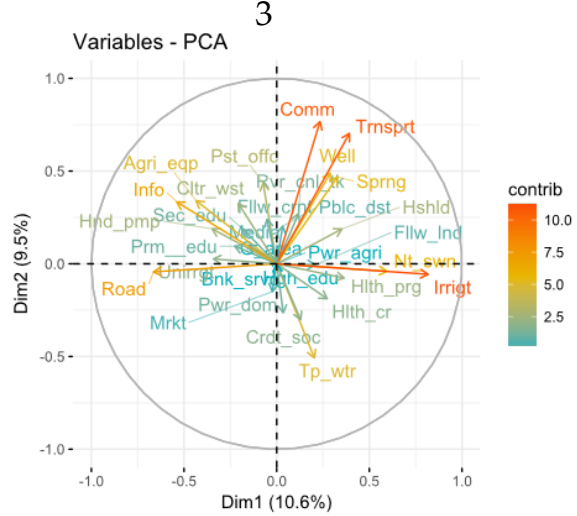

6

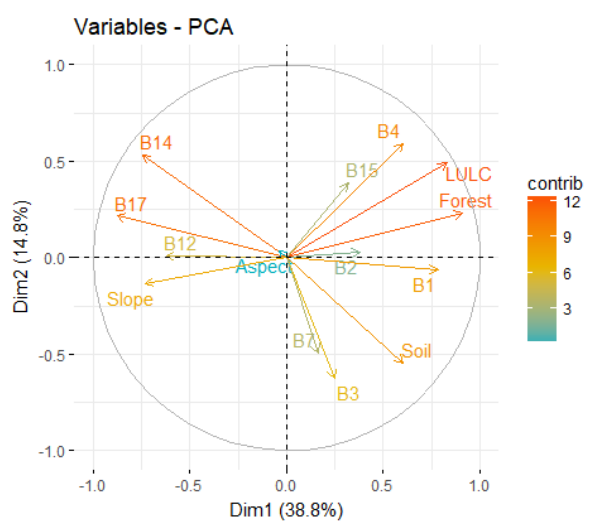

C

Figure A1. Variable contribution in the socio-economic unit clustering from units (1-6); and in the ecological unit clustering from units $(\mathbf{A}-\mathrm{C})$.

\section{References}

1. Martín-López, B.L.; Palomo, I.; García-Llorente, M.; Iniesta-Arandia, I.; Castro, A.J.; del Amo, D.G.; Gómez-Baggethun, E.; Montes, C. Delineating boundaries of social-ecological systems for landscape planning: A comprehensive spatial approach. Land Use Policy 2017, 66, 90-104. [CrossRef]

2. Gallopín, G.C.; Gutman, P. and Maletta, H. Global impoverishment, sustainable development and the environment: A conceptual approach. Int. Soc. Sci. J. 1989, 121, 375-397.

3. Berkes, F.; Folke, C. Linking Social and Ecological Systems: Management Practices and Social Mechanisms for Building Resilience; Cambridge University Press: Cambridge, UK, 1998.

4. Turner, B.L.; Matson, P.A.; McCarthy, J.J.; Corell, R.W.; Christensen, L.; Eckley, N.; Hovelsrud-Broda, G.K.; Kasperson, J.X.; Kasperson, R.E.; Luers, A.; et al. Illustrating the coupled human-environment system for vulnerability analysis: Three case studies. Proc. Natl. Acad. Sci. USA 2003, 100, 8080-8085. [CrossRef]

5. Liu, J.; Dietz, T.; Carpenter, S.R.; Alberti, M.; Folke, C.; Moran, E.; Pell, A.N.; Deadman, P.; Kratz, T.; Lubchenco, J.; et al. Complexity of Coupled Human and Natural Systems. Science 2007, 317, 1513-1516. [CrossRef] 
6. Ostrom, E. A General Framework for Analyzing Sustainability of Social-Ecological Systems. Science 2009, 325, 419-422. [CrossRef]

7. Turner, B.; Kasperson, R.E.; Meyer, W.B.; Dow, K.M.; Golding, D.; Kasperson, J.X.; Mitchell, R.C.; Ratick, S.J. Two types of global environmental change: Definitional and spatial-scale issues in their human dimensions. Glob. Environ. Chang. 1990, 1, 14-22. [CrossRef]

8. Vitousek, P.M.; Mooney, H.A.; Lubchenco, J.; Melillo, J.M. Human Domination of Earth's Ecosystems. Science 1997, 277, 494-499. [CrossRef]

9. Kates, R.W.; Clark, W.C. Our Common Journey: A Transition toward Sustainability; National Research Council: Washington, DC, USA, 1999.

10. Fairweather, J. Farmer models of socio-ecologic systems: Application of causal mapping across multiple locations. Ecol. Model. 2010, 221, 555-562. [CrossRef]

11. Abson, D.J.; Dougill, A.J.; Stringer, L. Using Principal Component Analysis for information-rich socio-ecological vulnerability mapping in Southern Africa. Appl. Geogr. 2012, 35, 515-524. [CrossRef]

12. Gupta, K.A.; Negi, M.; Nandy, S.; Kumar, M.; Singh, V.; Donatella, V.; Petrosillo, I.; Pandey, R. Mapping socio-environmental vulnerability to climate change in different altitude zones in the Indian Himalayas. Ecol. Indic. 2019, 109, 105787. [CrossRef]

13. Schneider, S.H.; Londer, R. The Coevolution of Climate and Life; Sierra Club Books: San Francisco, CA, USA, 1984.

14. Berkes, F.; Colding, J.; Folke, C. Navigating Social-Ecological Systems: Building Resilience for Complexity and Change; Cambridge University Press: Cambridge, UK, 2003; Volume 9.

15. Rosa, E.A.; Dietz, T. Climate Change and Society: Speculation, Construction and Scientific Investigation. Int. Sociol. 1998, 13, 421-455. [CrossRef]

16. Folke, C.; Hahn, T.; Olsson, P.; Norberg, J. Adaptive governance of social-ecological systems. Annu. Rev. Environ. Resour. 2005, 30, 441-473. [CrossRef]

17. Folke, C.; Pritchard, J.L.; Berkes, F.; Colding, J.; Svedin, U. The Problem of Fit between Ecosystems and Institutions: Ten Years Later. Ecol. Soc. 2007, 12. [CrossRef]

18. Glaser, M.; Krause, G.; Ratter, B.; Welp, M. Human/Nature Interaction in the Anthropocene Potential of Social-Ecological Systems Analysis. GAIA Ecol. Perspect. Sci. Soc. 2008, 17, 77-80. [CrossRef]

19. Gunderson, L.H.; Holling, C.S. (Eds.) Panarchy: Uderstanding Transformations in Human and Natural Systems; Island Press: Washington, DC, USA, 1998.

20. Levin, S.; Xepapadeas, T.; Crépin, A.-S.; Norberg, J.; de Zeeuw, A.; Folke, C.; Hughes, T.; Arrow, K.; Barrett, S.; Daily, G.; et al. Social-ecological systems as complex adaptive systems: Modeling and policy implications. Environ. Dev. Econ. 2012, 18, 111-132 [CrossRef]

21. Preiser, R.; Biggs, R.; de Vos, A.; Folke, C. Social-ecological systems as complex adaptive systems: Organizing principles for advancing research methods and approaches. Ecol. Soc. 2018, 23, 46. [CrossRef]

22. Dressel, S.; Ericsson, G.; Sandström, C. Mapping social-ecological systems to understand the challenges underlying wildlife management. Environ. Sci. Policy 2018, 84, 105-112. [CrossRef]

23. Dechazal, J.; Quétier, F.; Lavorel, S.; VanDoorn, A. Including multiple differing stakeholder values into vulnerability assessments of socio-ecological systems. Glob. Environ. Chang. 2008, 18, 508-520. [CrossRef]

24. McClanahan, T.R.; Castilla, J.C.; White, A.T.; Defeo, O. Healing small-scale fisheries by facilitating complex socio-ecological systems. Rev. Fish Biol. Fish. 2009, 19, 33-47. [CrossRef]

25. Castellarini, F.; Siebe, C.; Lazos, E.; de la Tejera, B.; Cotler, H.; Pacheco, C.; Boege, E.; Moreno, A.R.; Saldívar, A.; Larrazabal, A.; et al. A social-ecological spatial framework for policy design towards sustainability: Mexico as a study case. Investig. Ambient. Cienc. Política Pública 2014, 6, 45-59.

26. Auty, R.M. Resource Abundance and Economic Development; Oxford University Press: Oxford, UK, 2001.

27. Omernik, J.M. Ecoregions of the Conterminous United States. Ann. Assoc. Am. Geogr. 1987, 77, 118-125. [CrossRef]

28. Olson, D.M.; Dinerstein, E. The Global 200: A Representation Approach to Conserving the Earth's Most Biologically Valuable Ecoregions. Conserv. Biol. 1998, 12, 502-515. [CrossRef]

29. Cockburn, J.; Cundill, G.; Shackleton, S.; Rouget, M. Towards Place-Based Research to Support Social-Ecological Stewardship. Sustainability 2018, 10, 1434. [CrossRef]

30. Barreteau, O.; Giband, D.; Schoon, M.; Cerceau, J.; DeClerck, F.; Ghiotti, S.; James, T.; Masterson, V.A.; Mathevet, R.; Rode, S.; et al. Bringing together social-ecological system and territoire concepts to explore nature-society dynamics. Ecol. Soc. 2016, 21, 42. [CrossRef]

31. Hamann, M.; Biggs, R.; Reyers, B. Mapping social-ecological systems: Identifying 'green-loop' and 'red-loop' dynamics based on characteristic bundles of ecosystem service use. Glob. Environ. Chang. 2015, 34, 218-226. [CrossRef]

32. Wymann, S.; Ott, C.; Andreas, K.; Stillhardt, B. Will International Pursuit of the Millennium Development Goals Alleviate Poverty in Mountains? Mt. Res. Dev. 2006, 26, 4-8.

33. Ning, W.; Rawat, G.S.; Joshi, S.; Ismail, M.; Sharma, E. High-Altitude Rangelands and Their Interfaces in the Hindu Kush Himalayas; ICIMOD: Kathmandu, Nepal, 2013.

34. Singh, S.P.; Thadani, R. Complexities and Controversies in Himalayan Research: A Call for Collaboration and Rigor for Better Data. Mt. Res. Dev. 2015, 35, 401-409. [CrossRef] 
35. Gerlitz, J.Y.; Macchi, M.; Brooks, N.; Pandey, R.; Banerjee, S.; Jha, S.K. The Multidimensional Livelihood Vulnerabil-ity Index-An instrument to measure livelihood vulnerability to change in the Hindu Kush Himalayas. Clim. Dev. 2017, 9, 124-140. [CrossRef]

36. Kohler, T.; Maselli, D. (Eds.) Mountains and Climate Change_From Understanding to Action; Geographica Bernensia with the support of the Swiss Agency for Development and Cooperation (SDC), and an international team of contributors: Bern, Switzerland, 2009.

37. Egan, P.; Price, M. Mountain Ecosystem Services and Climate Change: A Global Overview of Potential Threats and Strategies for Adaptation; UNESCO: Paris, France, 2017.

38. Beniston, M. Climatic Change in Mountain Regions: A Review of Possible Impacts. Clim. Chang. 2003, 59, 5-31. [CrossRef]

39. Binder, C.R.; Hinkel, J.; Bots, P.W.G.; Pahl-Wostl, C. Comparison of Frameworks for Analyzing Social-ecological Systems. Ecol. Soc. 2013, 18, 26. [CrossRef]

40. Rissman, A.R.; Gillon, S. Where Are Ecology and Biodiversity in Social-Ecological Systems Research? A Review of Research Methods and Applied Recommendations. Conserv. Lett. 2016, 10, 86-93. [CrossRef]

41. ICIMOD. Mountain, Green Economy for Sustainable Development: A Concept Paper for Rio+20 and Beyond. In International Conference on Green Economy and Sustainable Mountain Development Opportunities and Challenges in View of Rio+20; ICIMOD: Kathmandu, Nepal, 2011.

42. Gerlitz, J.-Y.; Hunzai, K.; Hoermann, B. Mountain poverty in the Hindu-Kush Himalayas. Can. J. Dev. Stud. 2012, 33, 250-265. [CrossRef]

43. Pathak, D.; Gajurel, A.P.; Mool, P.K. Climate Change Impacts on Hazards in the Eastern Himalayas; ICIMOD: Kathmandu, Nepal, 2010.

44. ICIMOD. The Changing Himalayas: Impact of Climate Change on Water Resources and Livelihoods in the Greater Himalayas; ICIMOD: Kathmandu, Nepal, 2009.

45. Ray, M.; Doshi, N.; Alag, N.; Sreedhar, R. Climate Vulnerability in North Western Himalayas; Indian Network on Ethics and Climate Change (INECC): Visakhapatnam, India, 2011.

46. UAPCC. Uttarakhand Action Plan on Climate Change; Government of Uttarakhand: Dehradun, India, 2014.

47. Xu, J.; Grumbine, R.E.; Shrestha, A.; Eriksson, M.; Yang, X.; Wang, Y.U.N.; Wikes, A. The melting Himalayas: Cascading effects of climate change on water, biodiversity, and livelihoods. Conserv. Biol. 2009, 23, 520-530. [CrossRef]

48. Negi, G.C.S.; Samal, P.K.; Kuniyal, J.C.; Kothyari, B.P.; Sharma, R.K.; Dhyani, P.P. Impact of climate change on the western Himalayan mountain ecosystems: An overview. Trop. Ecol. 2012, 53, 345-356.

49. Madhura, R.K.; Krishnan, R.; Revadekar, J.; Mujumdar, M.; Goswami, B.N. Changes in western disturbances over the Western Himalayas in a warming environment. Clim. Dyn. 2015, 44, 1157-1168. [CrossRef]

50. Jing, F.; Leduc, B. Potential Threats from Climate Change to Human Wellbeing in the Eastern Himalayan Region; Climate Change Impact and Vulnerability in the Eastern Himalayas: Technical Report 6; ICIMOD: Kathmandu, Nepal, 2010.

51. Sarkar, S.; Kanungo, D.P.; Sharma, S. Landslide hazard assessment in the upper Alaknanda valley of Indian Himalayas. Geomat. Nat. Hazards Risk 2015, 6, 308-325. [CrossRef]

52. Chaudhary, P.; Bawa, K.S. Local perceptions of climate change validated by scientific evidence in the Himalayas. Biol. Lett. 2011, 7, 767-770. [CrossRef]

53. Tiwari, P.C.; Joshi, B. Environmental Changes and their Impact on Rural Water, Food, Livelihood and Health Security in Kumaon Himalayas. J. Urban Reg. Stud. Contemp. India 2014, 1, 1-12.

54. INCCA. 2010. Climate Change and India: A $4 \times 4$ Assessment. A Sectoral and Regional Analysis for 2030S; Ministry of Environment, Forests and Climate Change, Government of India: New Delhi, India, 2010.

55. Olsson, L.; Jerneck, A. Social fields and natural systems: Integrating knowledge about society and nature. Ecol. Soc. 2018, 23. [CrossRef]

56. ISFR. India State of Forest Report; Forest Survey of India, Ministry of Environment, Forests and Climate Change: Dehradun, India, 2019.

57. Barua, A.; Katyaini, S.; Mili, B.; Gooch, P. Climate change and poverty: Building resilience of rural mountain com-munities in South Sikkim, Eastern Himalaya, India. Reg. Environ. Chang. 2014, 14, 267-280. [CrossRef]

58. Pandey, R.; Bardsley, D.K. Social-ecological vulnerability to climate change in the Nepali Himalaya. Appl. Geogr. 2015, 64, 74-86. [CrossRef]

59. Hunzai, K.; Gerlitz, J.-Y.; Hoermann, B. Understanding Mountain Poverty in the Hindu Kush-Himalayas-Regional Report for Afghanistan, Bangladesh, Bhutan, China, India, Myanmar, Nepal, and Pakistan; International Centre for Integrated Mountain Development (ICIMOD): Kathmandu, Nepal, 2011.

60. Chakraborty, A.; Joshi, P.; Sachdeva, K. Predicting distribution of major forest tree species to potential impacts of climate change in the central Himalayan region. Ecol. Eng. 2016, 97, 593-609. [CrossRef]

61. Kaiser, H.F.; Rice, J. Little Jiffy, Mark IV. Educ. Psychol. Meas. 1974, 34, 111-117. [CrossRef]

62. Bartlett, M.S. The effect of standardization on a Chi-square approximation in factor analysis. Biometrika 1951, 38, 337-344.

63. Ward, J.H., Jr. Hierarchical Grouping to Optimize an Objective Function. J. Am. Stat. Assoc. 1963, 58, 236-244. [CrossRef]

64. Bateman, I.J.; Jones, A.P.; Lovett, A.A.; Lake, I.; Day, B.H. Applying Geographical Information Systems (GIS) to Environmental and Resource Economics. Environ. Resour. Econ. 2002, 22, 219-269. [CrossRef]

65. Maes, J.; Egoh, B.; Willemen, L.; Liquete, C.; Vihervaara, P.; Schägner, J.P.; Grizzetti, B.; Drakou, E.; La Notte, A.; Zulian, G.; et al. Mapping ecosystem services for policy support and decision making in the European Union. Ecosyst. Serv. 2012, 1, 31-39. [CrossRef] 
66. Roy, P.; Joshi, P.K.; Shavindar, S.; Agarwal, S.; Drswapanil, Y.; Jeganathan, C. Biome mapping in India using vegetation type map derived using temporal satellite data and environmental parameters. Ecol. Model. 2006, 197, 148-158. [CrossRef]

67. Ellis, R.; Ramankutty, N. Putting people in the map: Anthropogenic biomes of the world. Front. Ecol. 2008, 6, 439-447. [CrossRef]

68. Ellis, E.C.; Klein Goldewijk, K.; Siebert, S.; Lightman, D.; Ramankutty, N. Anthropogenic transformation of the biomes, 1700 to 2000. Glob. Ecol. Biogeogr. 2010, 19, 589-606. [CrossRef]

69. Singh, J.S.; Singh, S.P. Forests of Himalaya: Structure, Functioning and Impact of Man; Gyanodaya Prakashan: Nainital, India, 1992.

70. Singh, J.S. Man and Forest Interactions in Central Himalaya. In Himalayan Environment and Development: Problems and Perspectives; Gyanodaya Prakashan: Almora, India, 1992.

71. Joshi, A.K.; Joshi, P.K. Forest Ecosystem Services in the Central Himalaya: Local Benefits and Global Relevance. In Proceedings of the National Academy of Sciences, India Section B: Biological Sciences; Springer: Berlin/Heidelberg, Germany, 2018; Volume 89, pp. 785-792.

72. Leslie, H.M.; Basurto, X.; Nenadovic, M.; Sievanen, L.; Cavanaugh, K.C.; Cota-Nieto, J.J.; Erisman, B.E.; Finkbeiner, E.; Hi-nojosaArango, G.; Moreno-Baez, M.; et al. Operationalizing the social-ecological systems framework to assess sustainability. Proc. Natl. Acad. Sci. USA 2015, 112, 5979-5984. [CrossRef]

73. Hinkel, J.; Bots, P.W.G.; Schlüter, M. Enhancing the Ostrom social-ecological system framework through formalization. Ecol. Soc. 2014, 19, 51. [CrossRef]

74. Jolliffe, I.T.; Cadima, J. Principal component analysis: A review and recent developments. Philos. Trans. R. Soc. A Math. Phys. Eng. Sci. 2016, 374, 20150202. [CrossRef] [PubMed]

75. Bailey, R.G. Ecosystem Geography: From Ecoregions to Sites; Springer: New York, NY, USA, 2009.

76. Balvanera, P.; Calderón-Contreras, R.; Castro, A.J.; Felipe-Lucia, M.R.; Geijzendorffer, I.R.; Jacobs, S.; Martín-López, B.; Arbieu, U.; Speranza, C.I.; Locatelli, B.; et al. Interconnected place-based social-ecological research can inform global sustainability. Current Opin. Environ. Sustain. 2017, 29, 1-7. [CrossRef]

77. Fasona, M.; Adeonipekun, P.A.; Agboola, O.; Akintuyi, A.; Bello, A.; Ogundipe, O.; Soneye, A.; Omojola, A. Incentives for collaborative governance of natural resources: A case study of forest management in southwest Nigeria. Environ. Dev. 2019, 30, 76-88. [CrossRef]

78. Liehr, S.; Röhrig, J.; Mehring, M.; Kluge, T. How the Social-Ecological Systems Concept Can Guide Transdisciplinary Research and Implementation: Addressing Water Challenges in Central Northern Namibia. Sustainability 2017, 9, 1109. [CrossRef]

79. Pandey, R.; Kumar, P.; Archie, K.M.; Gupta, A.K.; Joshi, P.; Valente, D.; Petrosillo, I. Climate change adaptation in the westernHimalayas: Household level perspectives on impacts and barriers. Ecol. Indic. 2018, 84, 27-37. [CrossRef]

80. Berrouet, L.M.; Machado, J.; Villegas-Palacio, C. Vulnerability of socio-ecological systems: A conceptual Framework. Ecol. Indic. 2018, 84, 632-647. [CrossRef]

81. Schoon, M.; van der Leeuw, S. The shift toward social-ecological systems perspectives: Insights into the human-nature relationship. Nat. Sci. Soc. 2015, 23, 166-174. [CrossRef]

82. Rodgers, W.A.; Panwar, H.S.; Mathur, V.B. Wildlife Protected Area Network in India: A Review (Executive Summary); Report; Wildlife Institute of India: Dehradun, India, 2000.

83. Galaz, V.; Olsson, P.; Hahn, T.; Folke, C.; Svedin, U. The Problem of Fit among Biophysical Systems, Environmental and Resource Regimes, and Broader Governance Systems: Insights and Emerging Challenges. In Institutions and Environmental Change; The MIT Press: Cambridge, MA, USA, 2008; pp. 147-186. 